ص ص [234- 225]

\author{
الحوافز وأثرها في الرضا الوظيفي

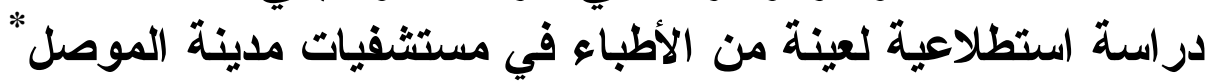 \\ مثنى وعد الله يونس \\ دبلوم عالي تخصصي في الإدارة و ادارة المستشفيات \\ الدكتورجرجيس غُمير عباس \\ أستاذ مساعد- قسم ادارة الاعمال \\ كلية الإدارة و الاقتصاد - جامعة الموصل \\ Jarjesabbas@yahoo.com
}

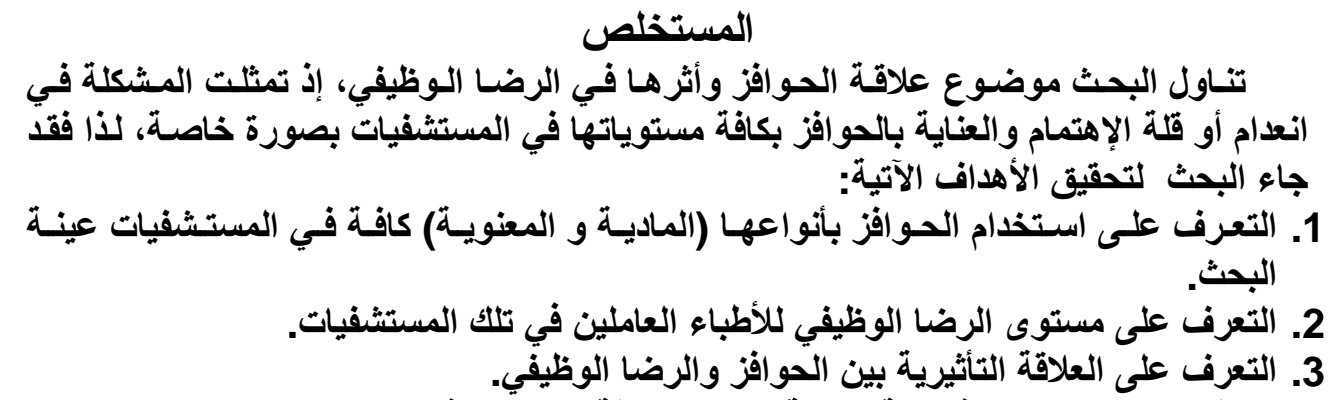

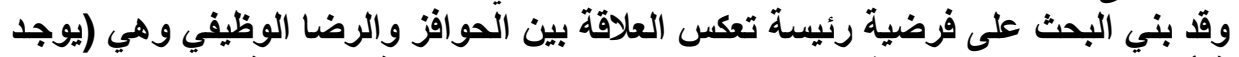

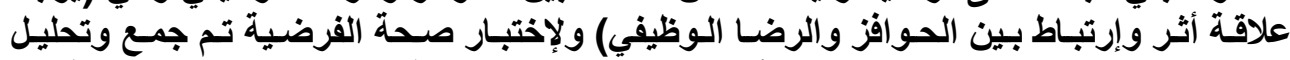

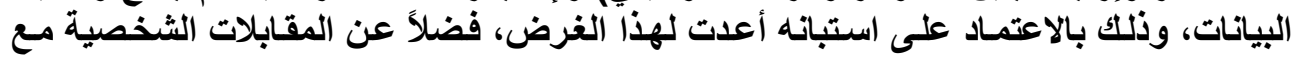

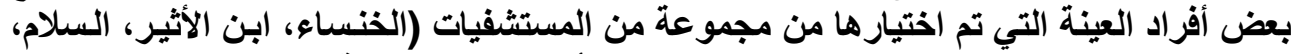

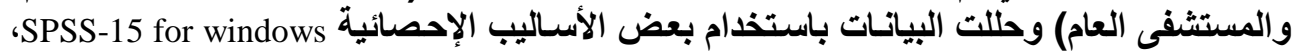

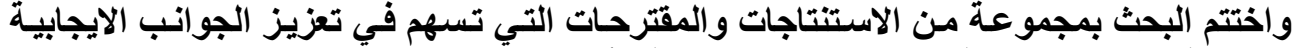

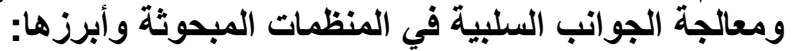
1. إن الأجور التي تقدمها للأطباء غير كافية. 2. عدم وجود مكأفآت للعمل الإضافي.

* البحث مستل من رسالة الدبلوم .

تأريخ قبول النشر 2008/11/24 تأريخ استلام البحث 2008/5/28 


\title{
Motivations And Its Effect On Job Satisfaction Study Apilot To Sample On Doctors In Hospitals Of Mousl City
}

\author{
Jarjees O. Abbas (PhD) \\ Department of Business Administration \\ University of Mosul
}

\author{
Mothanna W. Younis \\ Higher Diploma of Health Management
}

\begin{abstract}
This research deals the relations between the incentive and job satisfaction, the problem of research was represented by lack or littleness for inventive in all level especially in hospitals so this research to aim at:

1. Identifying the use of incentives in all types in the hospital s sample of study.

2. Identifying the level of job satisfaction between the doctors who is working in hospital.

3. Identifying the effect relation between the incentive and job satisfaction.

The structure of a hypothesis mainly reflect the relationship between motivation and job satisfaction is (there is a correlation between the impact of the incentives and career satisfaction) and to test the validity of the hypothesis has been collected and analyzed data by adopting the resolution prepared for this purpose as well as personal interviews with some of the sample, which was chosen from a group hospitals (khan'aa , Ibin Al-Atheer, Al-Salam and General Hospital) and analyzed the data using some statistical methods (Spss-15 for windows), and concluded series of findings and proposals that contributed to the strengthening the positive aspect and address the negative aspects of the organizations discussed, namely:

1. The wages offered to the doctors are inadequate.

2. The absence of rewards for overtime.

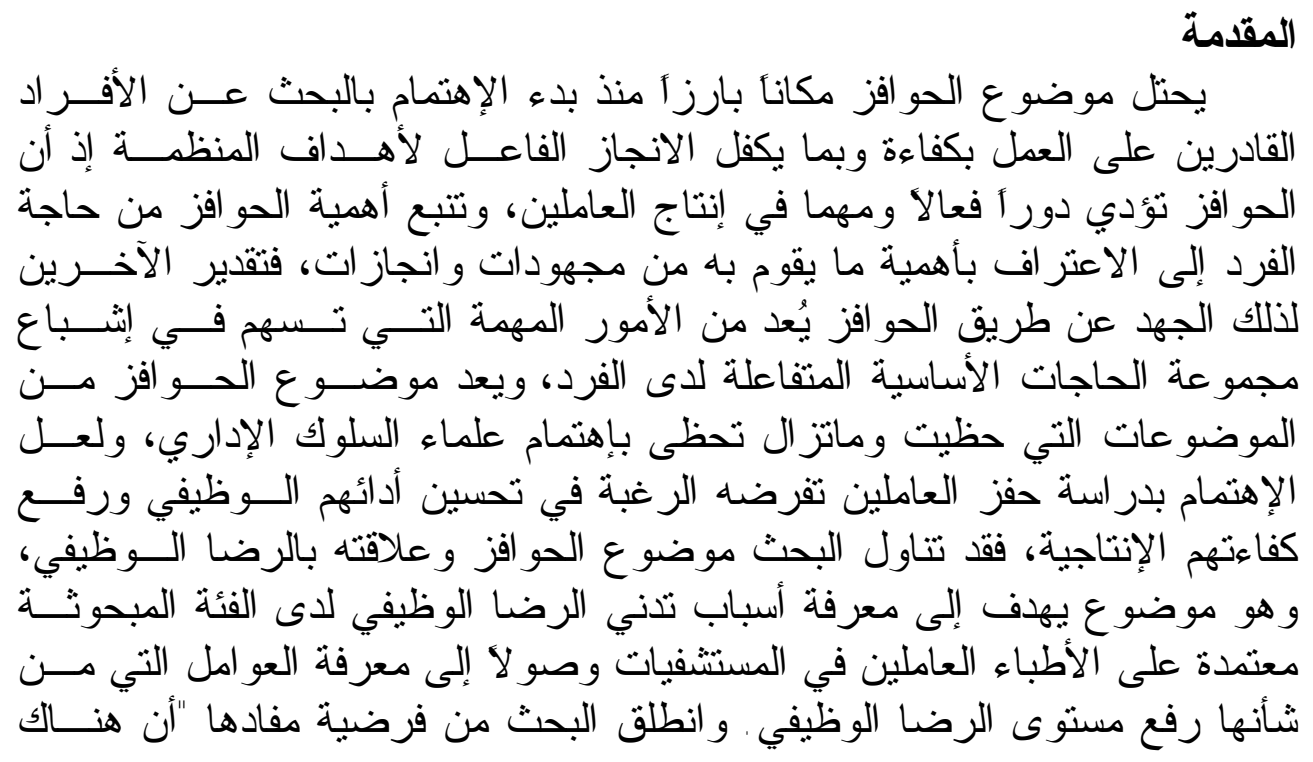




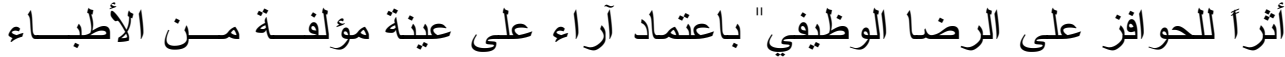

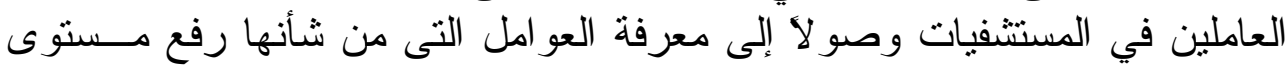

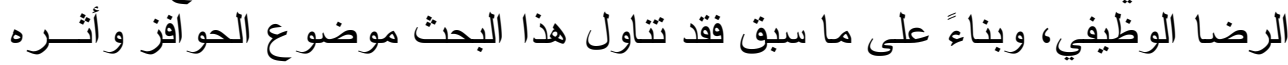

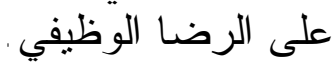

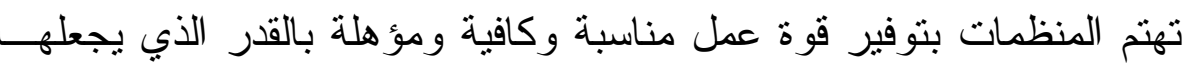
منهجية البحث مشكلة البحث المث

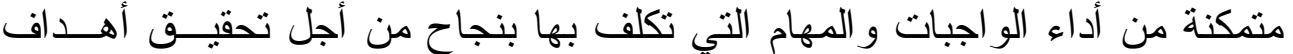

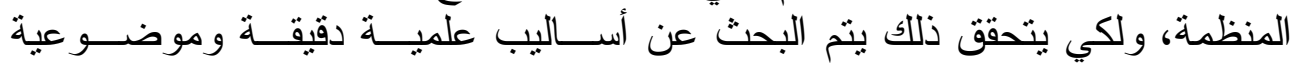

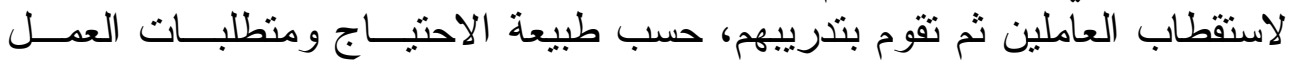

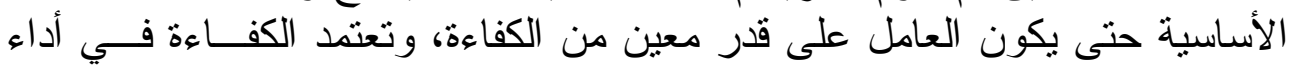

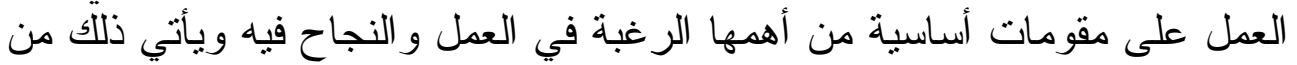

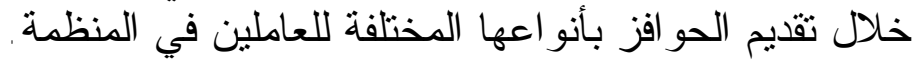

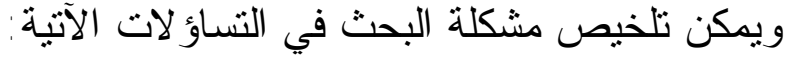

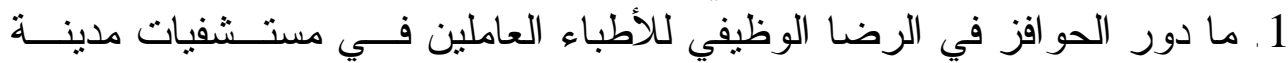

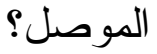

2. ما أكثر أنو اع الحو افز أهمية من وجهة نظر العاملين فــي مستـشفيات مدينــة

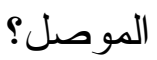

3. هل توجد علاقة بين الحو افز و الرضا الوظيفي للأطباء العاملين في مستـشفيات

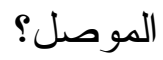

$$
\text { أهمية البحث أهمية البحث في: }
$$

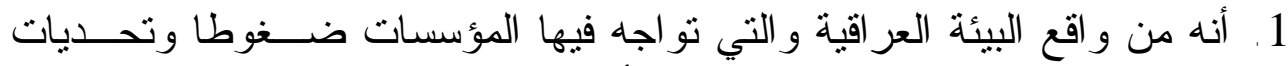

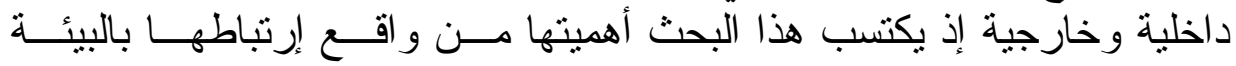

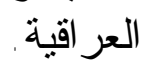

2. كونه يمثل إسهاماً في تسليط الضوء علئ على هذا الموضوع الحيوي و المهم و الذي

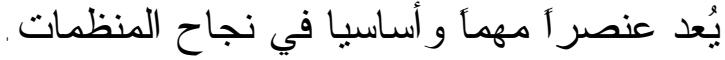

3. الدور الذي تؤديه الحو افز بأنو اعها (مادية ومعنوية) في إرتفاع مستوى الرضا

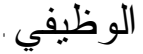

$$
\text { أهداف البحث البحث إلى: }
$$




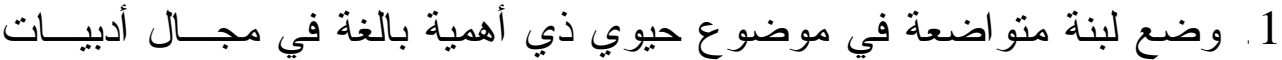

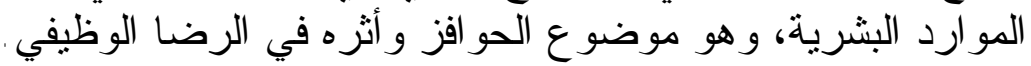

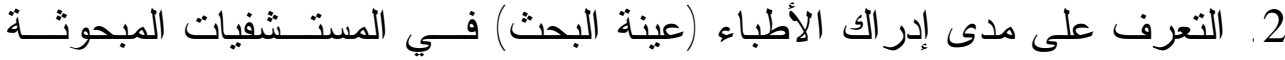

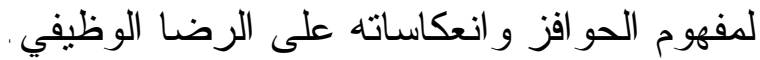

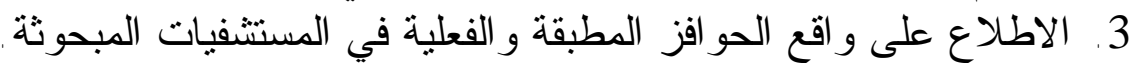
4. تحليل طبيعة العلاقة المتداخلة بين الحو افز (المادية و المعنوية) و الرضا الرئا الوظيفي

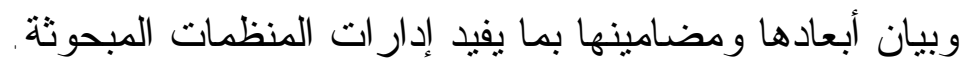

فرضيات البحث إعتمد البحث فرضيتين رئيسيتين هما:

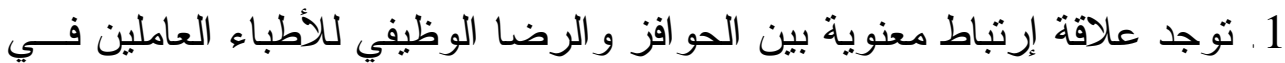
مستشفيات مدينة الموصل . 2. يوجد أثز ذو دلالة معنوية بين متغيري الحو افز و الرضنا الوظيفي.

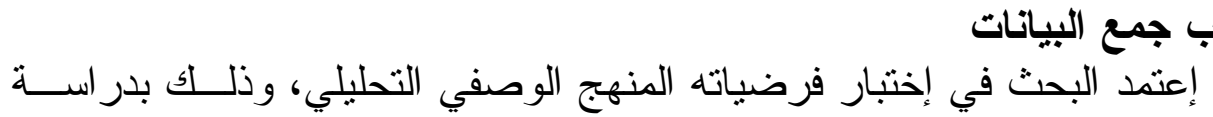
العلاقات بين المتغير ات الرئيسة، وبغية الحصول على البيانات و المعلومات اللازمة لإنية

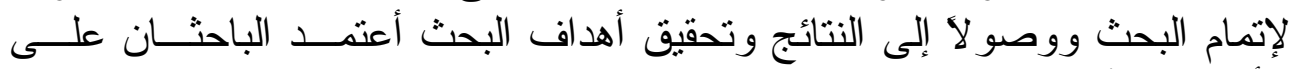

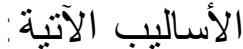

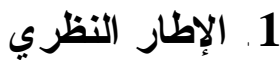

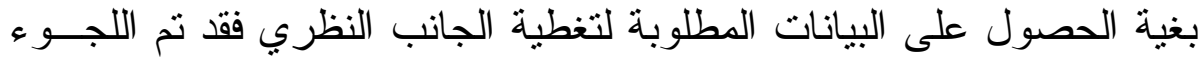

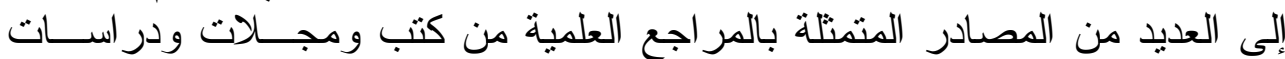

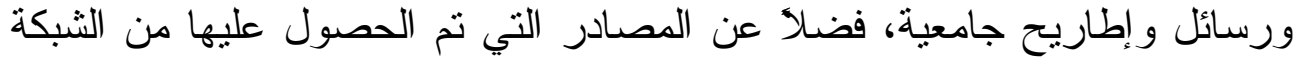

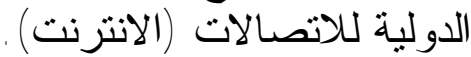

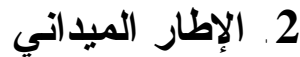
أمـا فيما يخص الجيدي الجانب الميداني فقد استخدمت الوســائل الآتيــة فــي جمـع

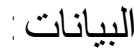
أ. المقابلات الشخصية: مع أفر اد عينة الدراسة بهدف توضيح فقر ات الاستبانة في

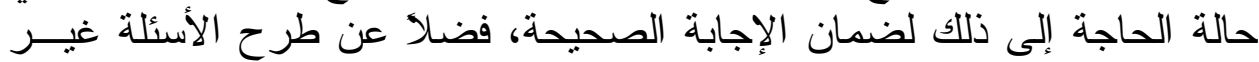

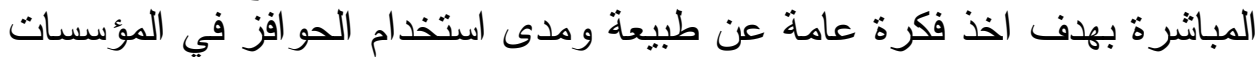

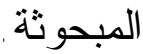

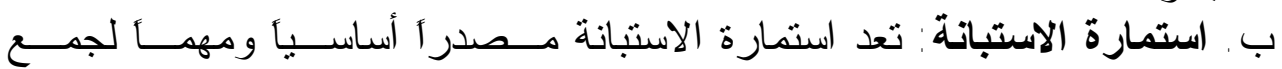

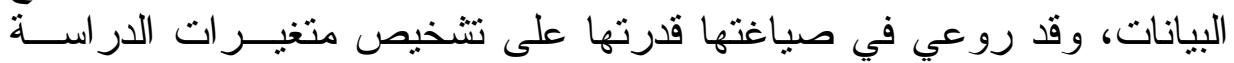

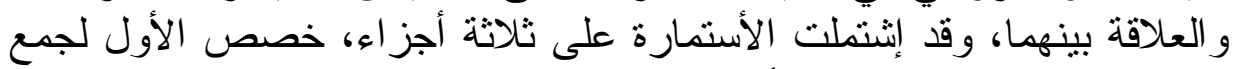

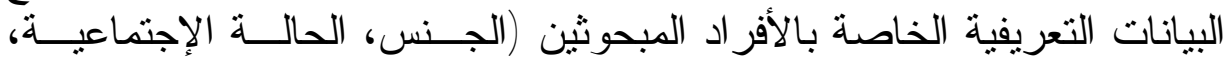




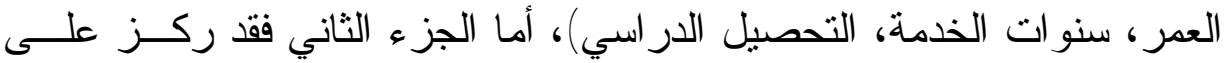

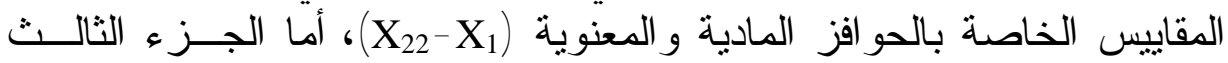
فخصص لمقاييس الرضا الوظيفي (X)

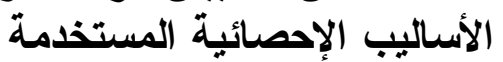

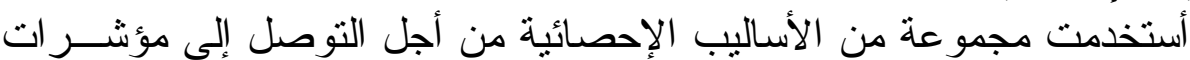

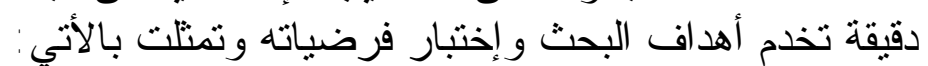
1. التكر ار ات و النسب المئوية و المتوسطات الحسابية و الإنحر افات المعيارية لكونها

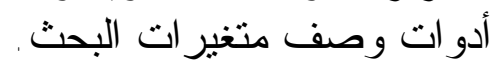
2. الإرتباط البسيط و المتعدد لقياس العلاقة بين متغير ات البحث.

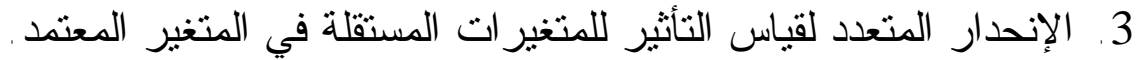

حدود الارسة اسلة 1. الحدود الزمانية: أجريّ البحث إختبار اته الميدانية للمدة مــن شــهر حزيــران

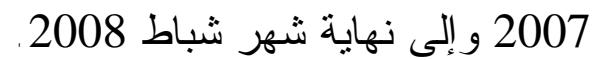

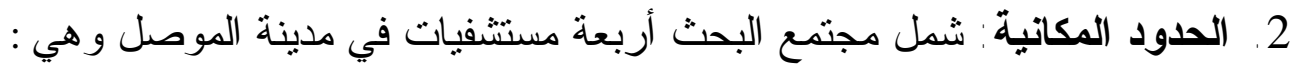

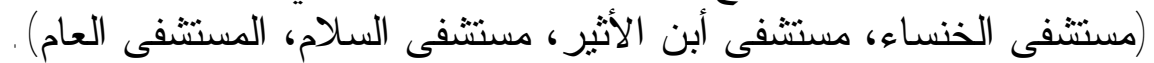

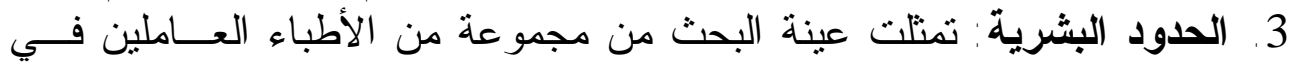
المستشفيات المذكورة آنفأ.

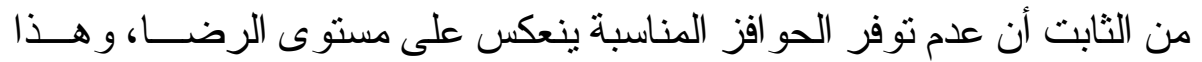

الحوافز

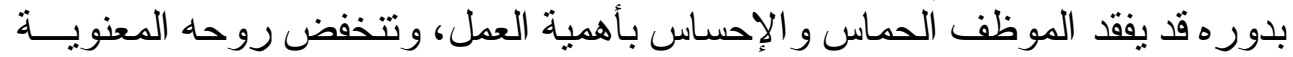

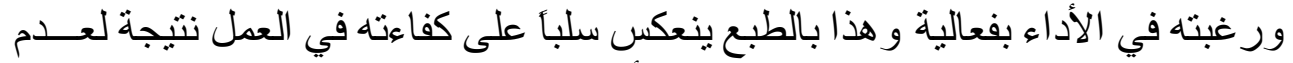

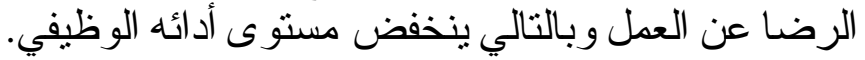

أولاً - مفهوم الحوافز افز

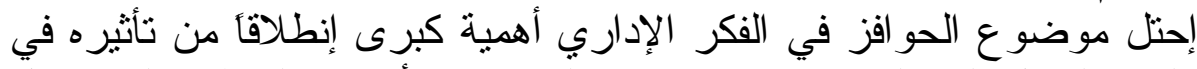

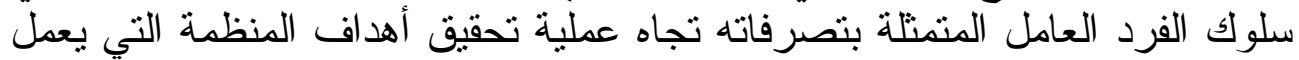

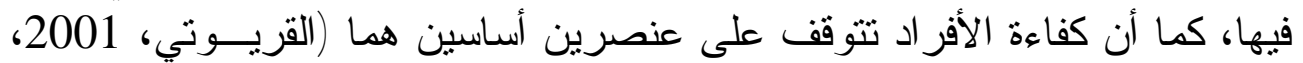
$:(288$

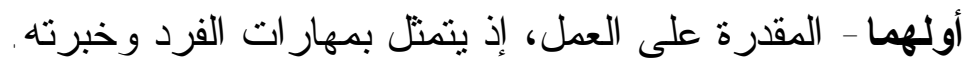

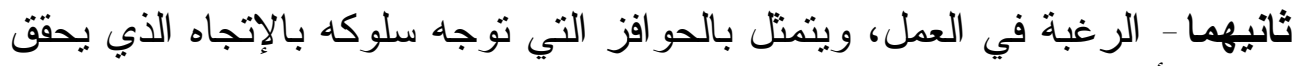
أهداف المنظمة.

وقد وردت تعاريف عديدة للحو افز من قبل العديد من الباحثنين وكانت وجهات

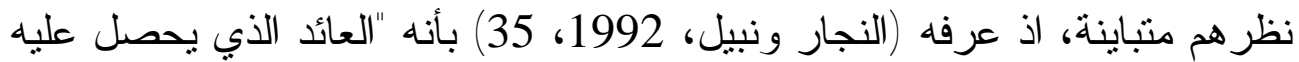




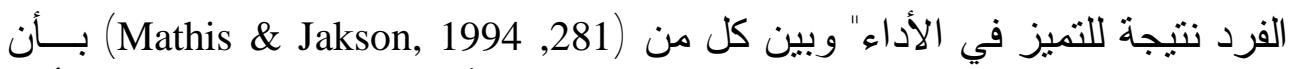

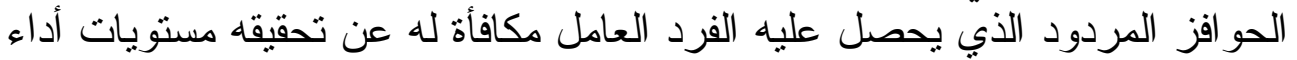

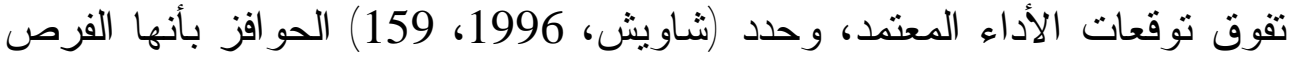

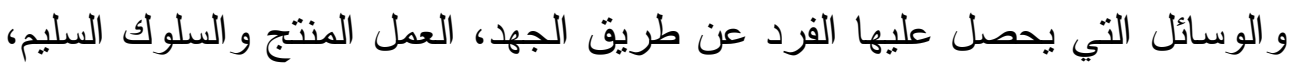
وذللك لاشباع حاجاته التي يحس ويشعر بها و التي تحتاج إلى إنشباع.

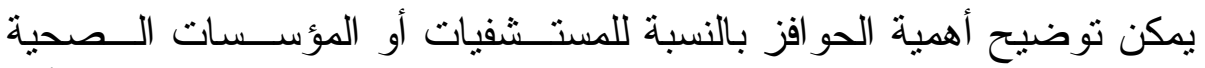
عمومأ بغض النظر عن نوع منتجاتها النها على وجه الخصوص من خلال النقاط الآتية

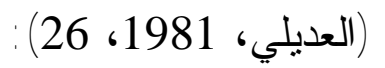

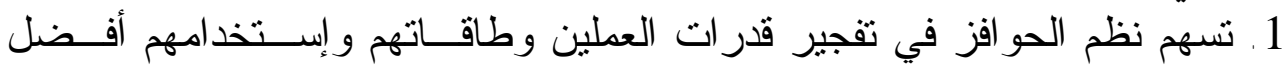

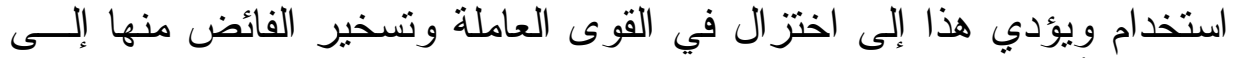

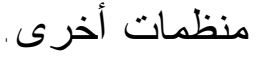

2. تحسين الوضع المادي و المعنوي و النفسي و الإجتماعي للفرد وربط مصالح الفرد بالمنظمة.

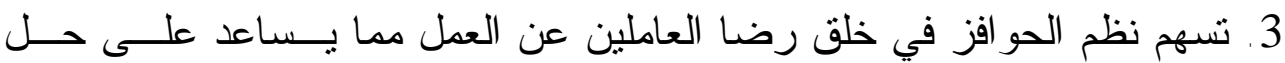

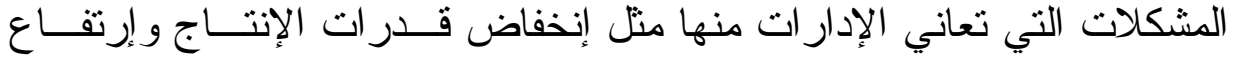

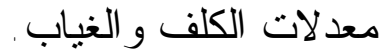
4. تعمل على زيادة الإنتاج فضلا عن خفض التكاليف.

$$
\text { ثالثاً - أنواع الحوافز }
$$

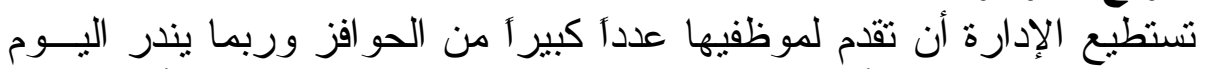

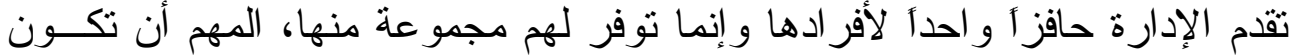

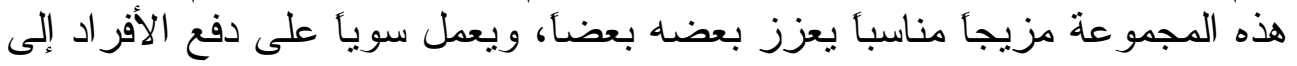
مزيد من الجهد وزيادة الإنتاج.

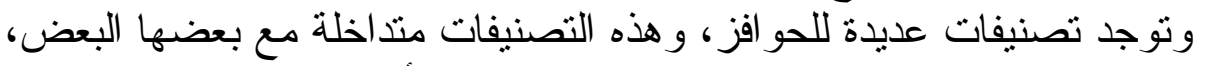

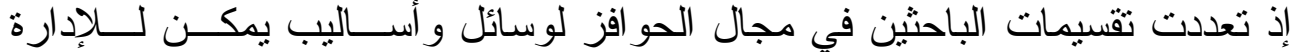

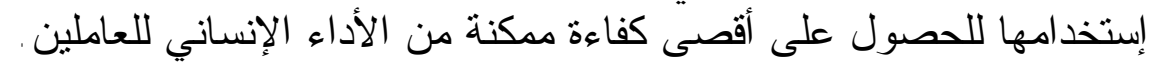

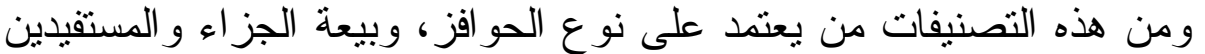

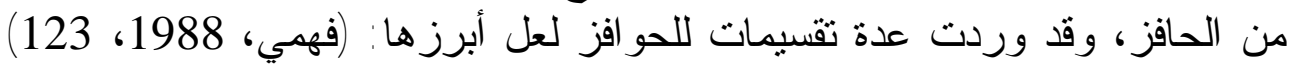

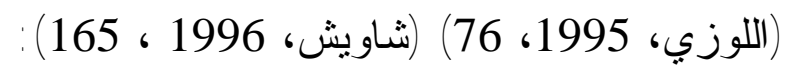

التصنيف الأول - الحوافز من حيث طبيعتها أو قيمتها

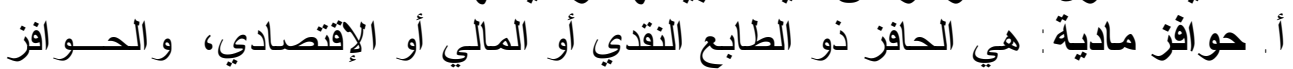

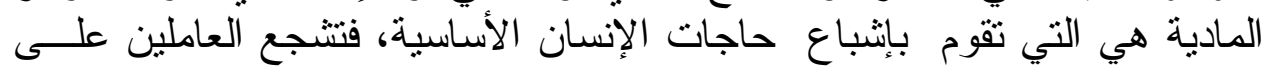




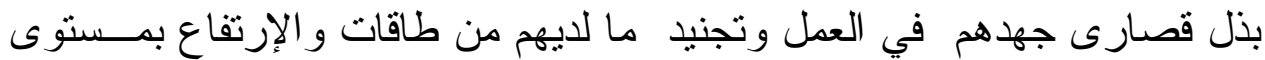

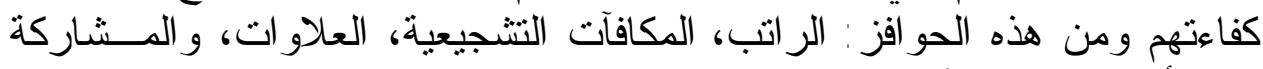

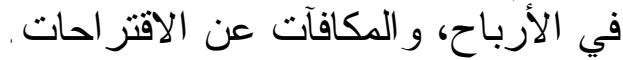

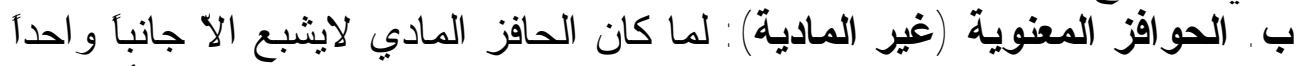

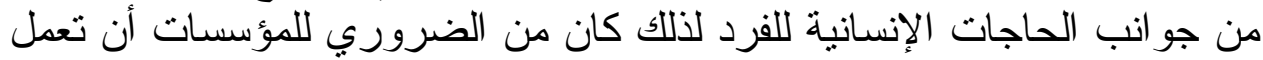

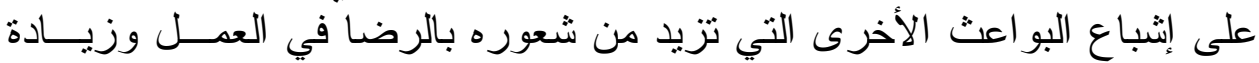

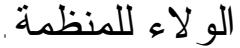

\section{التصنيف الثاني - الحوافز من حيث الأثر}

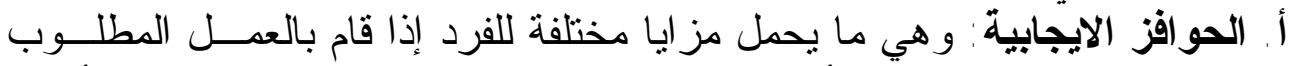

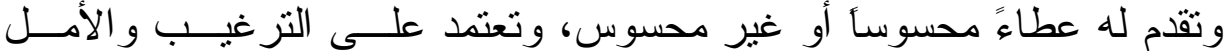

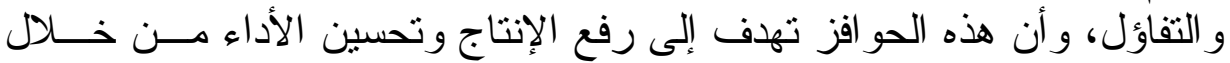

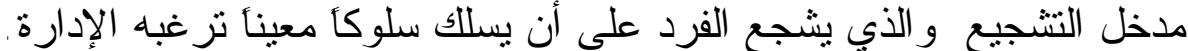

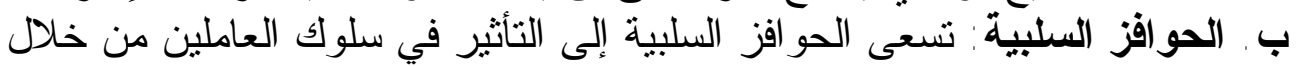

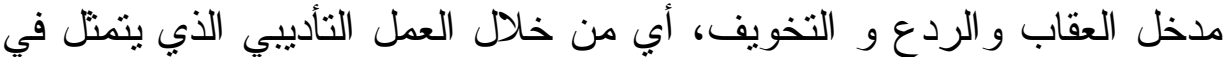

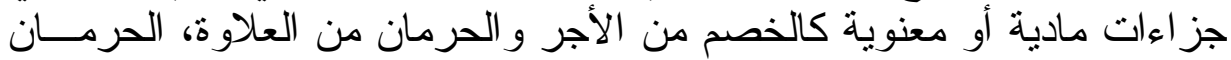

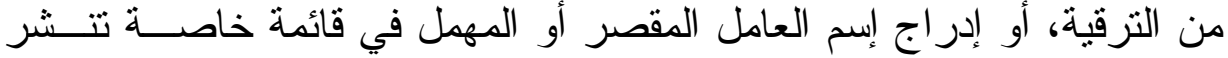
على العاملين في المنشأة.

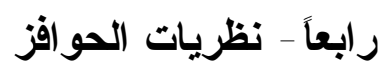

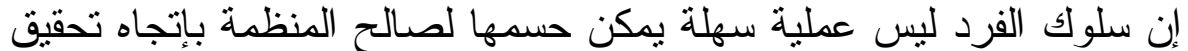

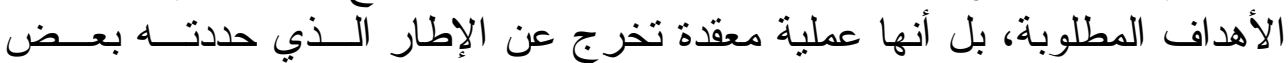
النظريات في الإدارة، ولذلك لابد من أخذ هذه النظريات بنظر الإعتبار ولعل مسن الإنـ

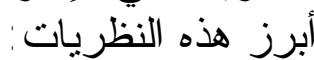

\section{أولاً - النظرية (الكلاسيكية}

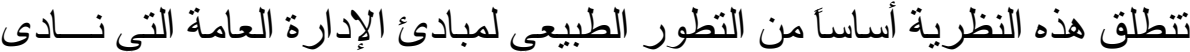

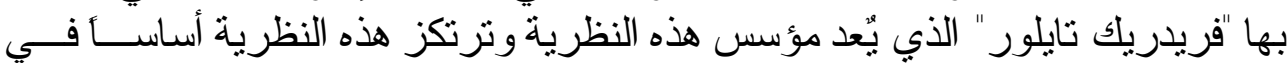

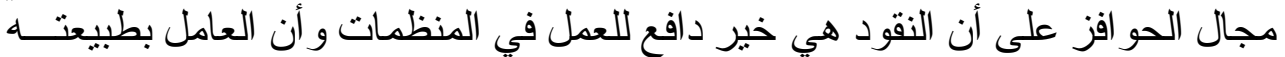

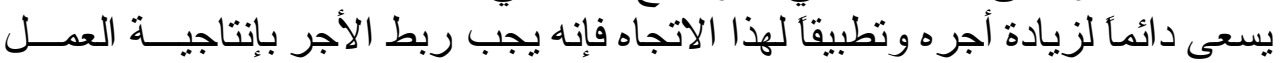

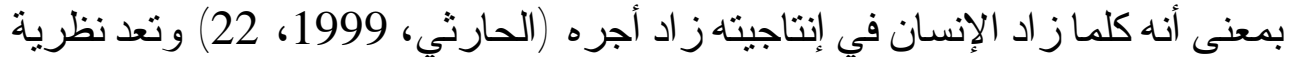

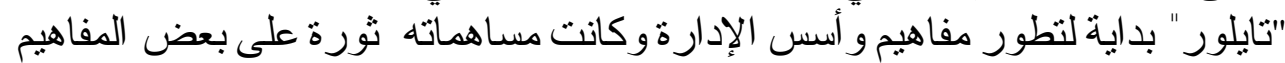

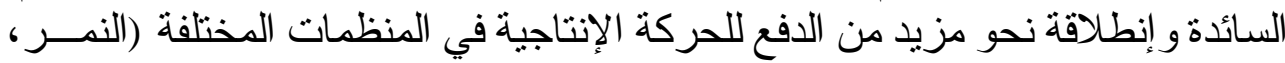




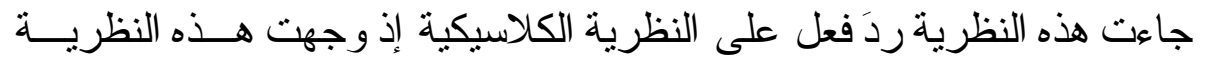

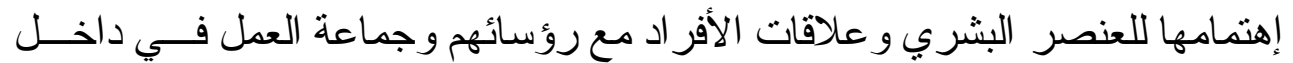

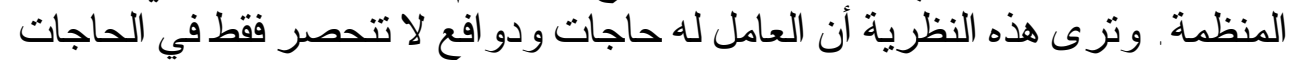

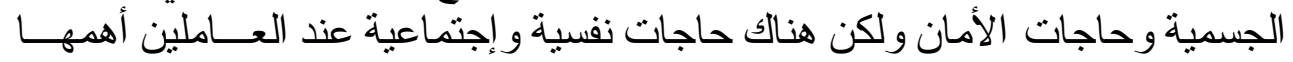

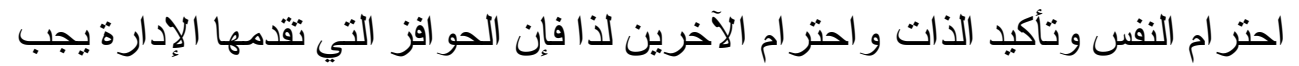

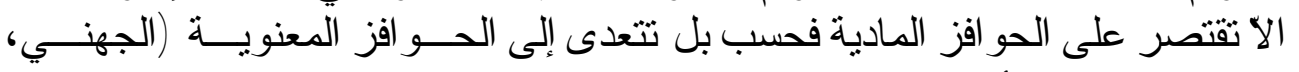

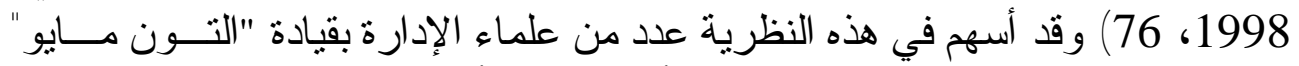

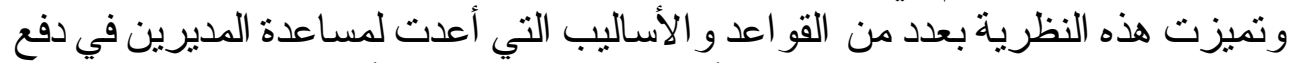
العاملين وتحفيز هم وتركز مجمو عة الأساليب هذه على ثلاثة أنثطة إدارية رئيسة هي:

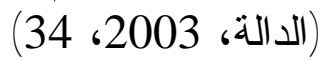
أ. تشجيع العاملين على المشاركة في القر ار ات الإدارية.

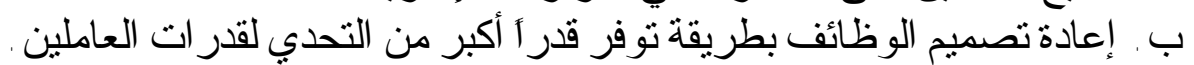
ج. المشاركة في نشاطات المنظمة وتحسين تدفق الاتصال بين الرئيس ونئ و المرؤوسين.

ثالثاً - نظريات الحاجات الإسانية

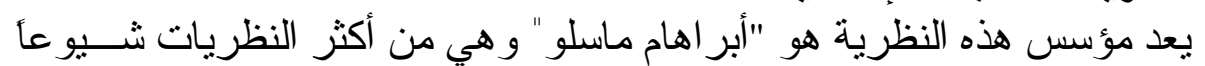

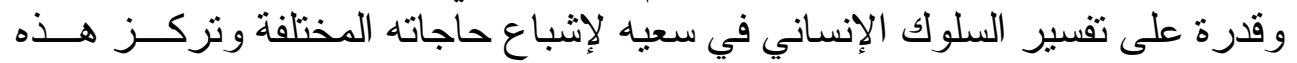

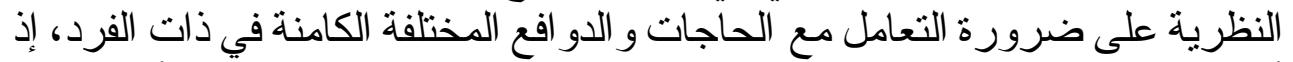

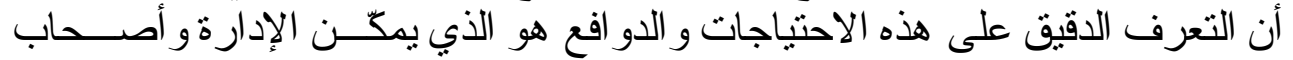
القر ار من وضع وتطبيق نظم الحفز لدى المؤسسة أو المنظمة. لألئ.

\section{خامساً - العو امل المؤثرة في أنظمة الحو افز}

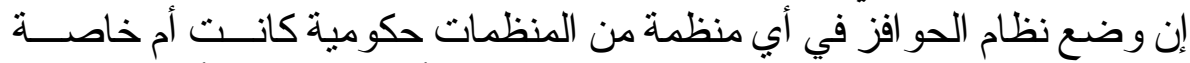
يتأثر بعدد من العو امل التي يجب مر اعاتها قبل التخطيط لأنظمة الحو افز ألثائه وهي:

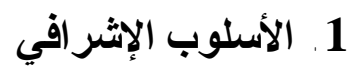

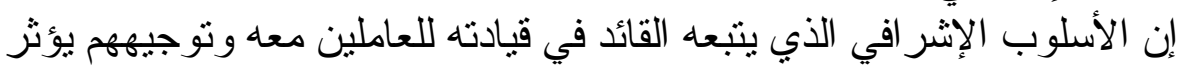

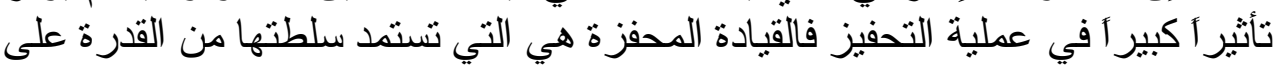

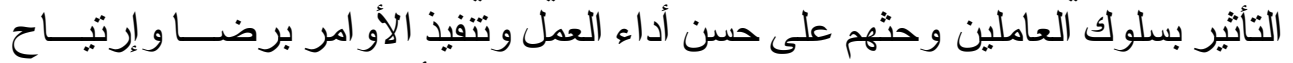
وليس عن خوف من العقاب و الدفهوم الإداري لذللك يجب أن تكون القيادة ديمقر اطية.

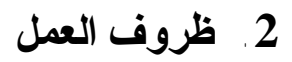

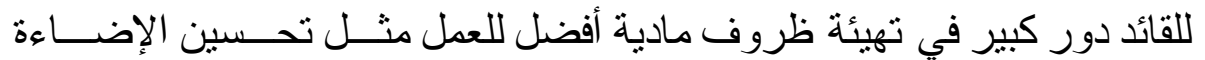

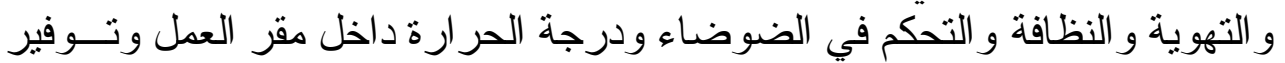

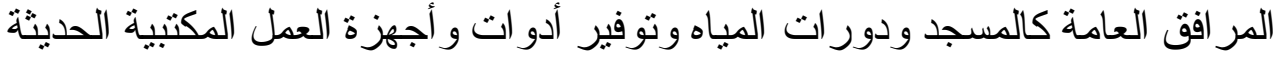

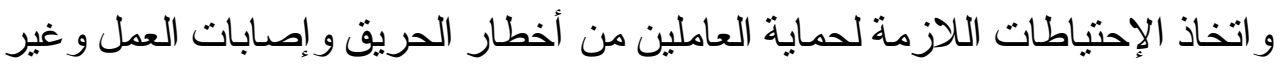

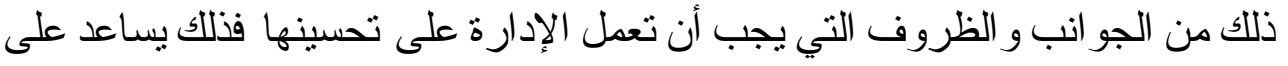


زيادة الإنتاجية ورفع الروح المعنوية بين العاملين (دره، 1982، 98) فكلما كانستـ

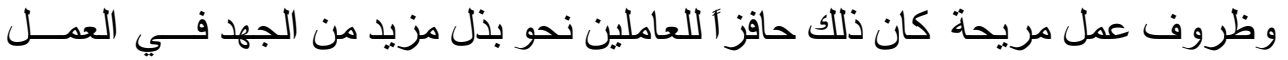

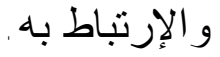

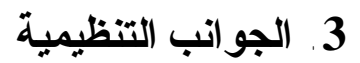

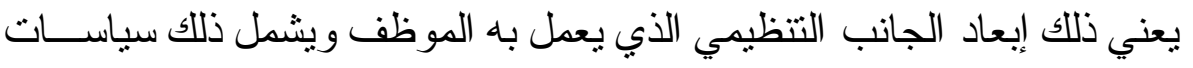

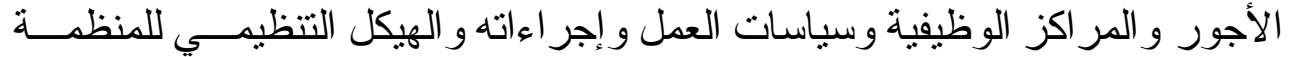

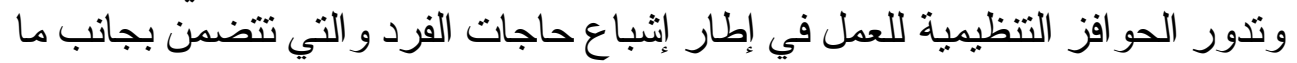

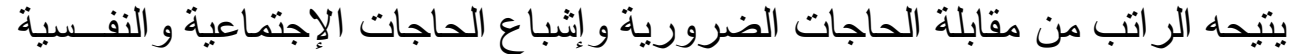

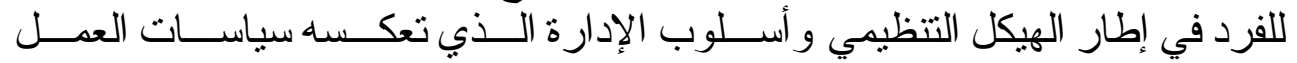

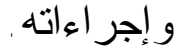

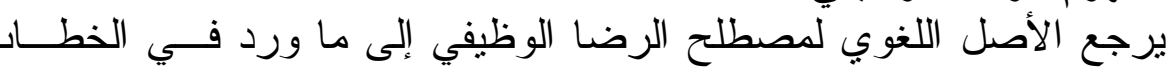

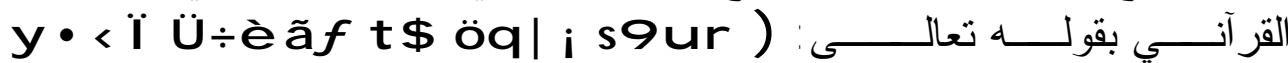

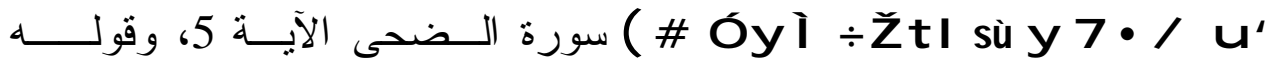
( \# q

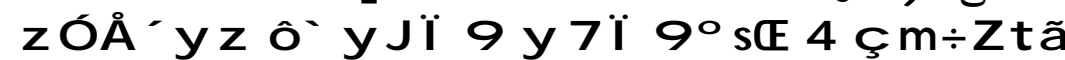

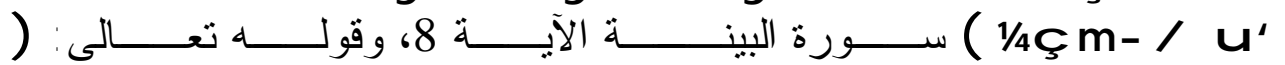

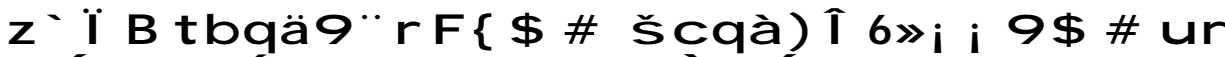
Õë\$ | iRF\{\$ \# ur t ${ }^{\circ}$ ÔÁ ç...f a y g fl J ${ }^{-} 9$ \$ \#

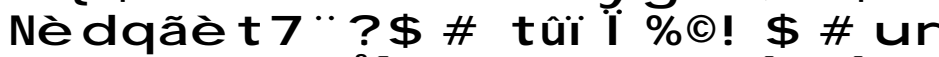

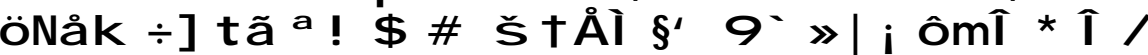

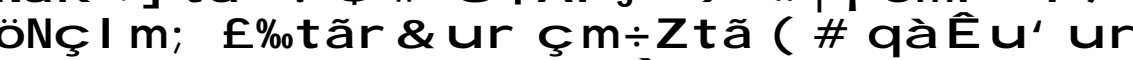

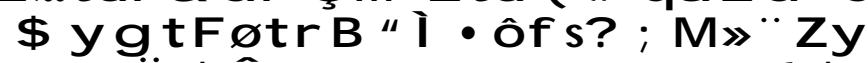

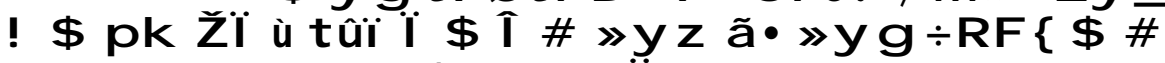
"ó `qx

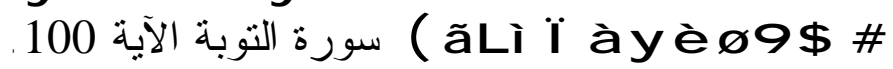

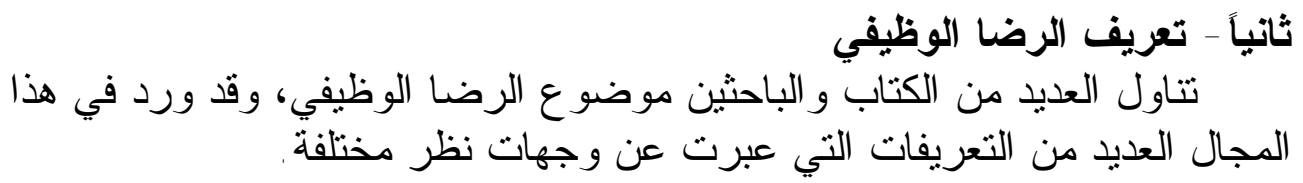

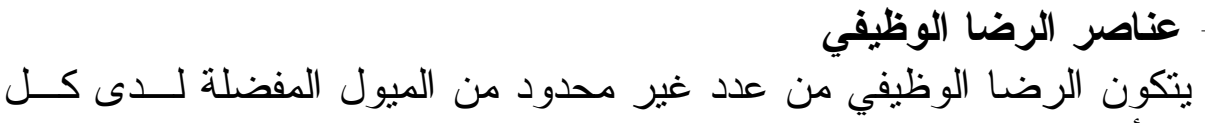

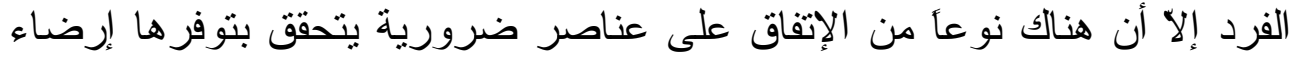


الفرد ضروريأ، وتقسم هذه العناصر إلى مجمو عات مختلفة تتفاوت أهميتها حسسب وجهات نظر كل كاتب وكما في الجدول 2:

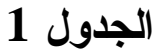

بعض تعريفات الرضا الوظيفي

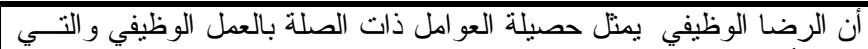

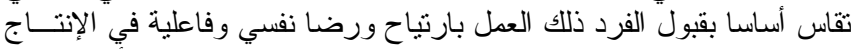

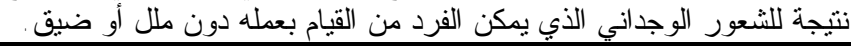

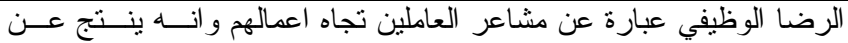

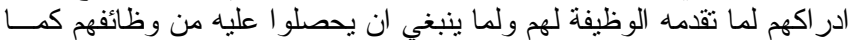
انه محصلة للاتجاهات الخاصة نحو مختلف العناصر المنعلقة بالعمل المنمئلة

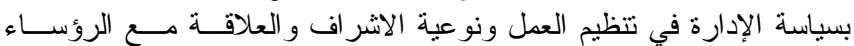

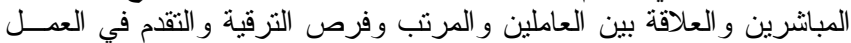

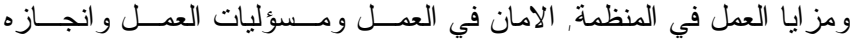

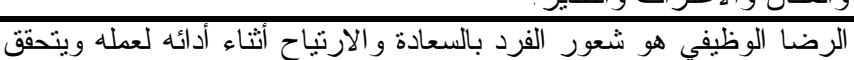

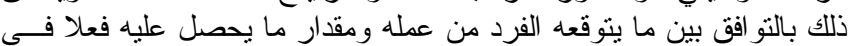

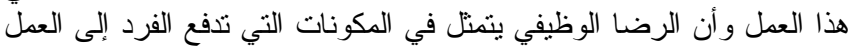

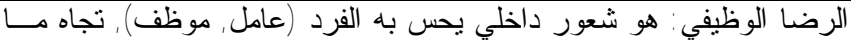

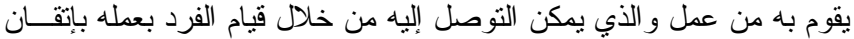

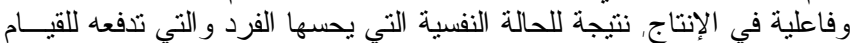

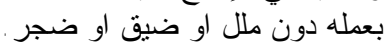

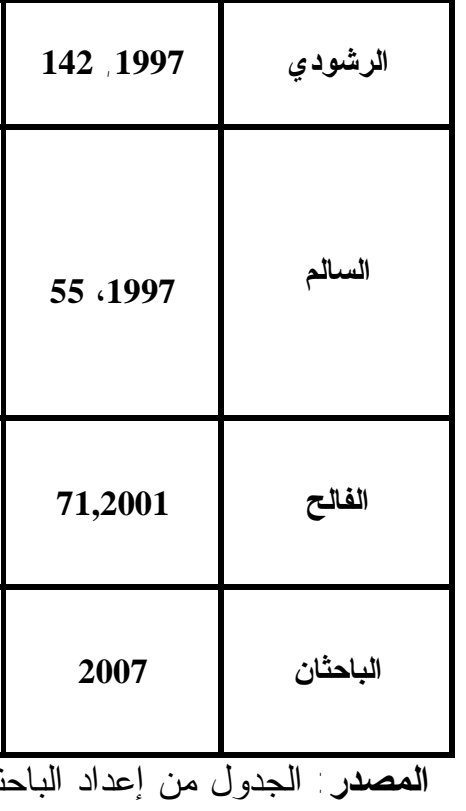

$$
\text { المصدر: الجدول من إعداد الباحثان بالرجوع إلى المصادر اعلاه. }
$$

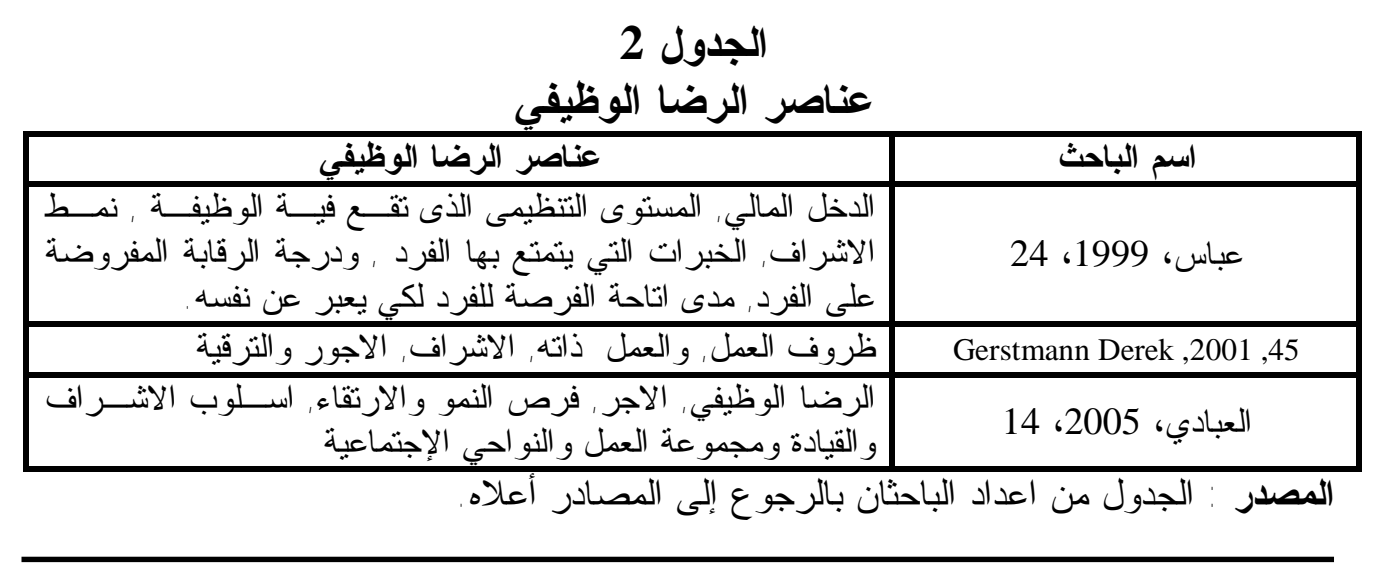




$$
\begin{aligned}
& \text { رابعاً - نظريات الرضا الوظيفي } \\
& \text { هنالك العديد من النظريات التي التياتيفيات تناولت الرضا الوظيفي ولعل أبرزها: } \\
& \text { 1. نظرية العدالة و المساواة }
\end{aligned}
$$

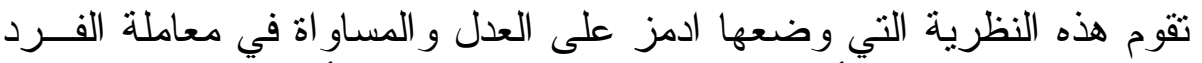

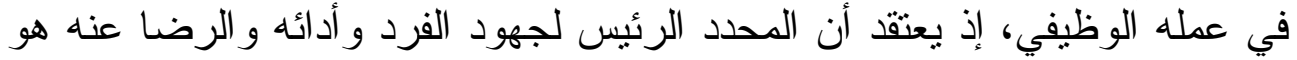
درجة العدالة و المساو اة التي يدركها الفرد في وظيفته .

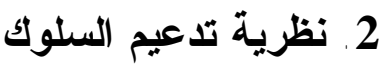

وضع سكينر نظرية تدعيم السلوك التي تتطلق من فكرة أن السلوك الإنساني

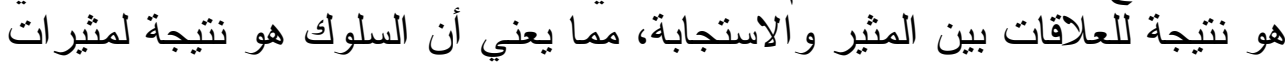

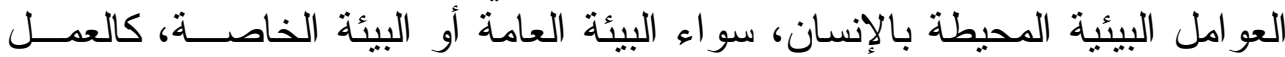
الوظيفي و البيئة الإدارية. 3. نظرية التكيف الوظيفي

تم تطوير هذه النظرية باستخدام استفتاء منيسوتا للرضا الوظيفي الوظيفي فقد قام كل

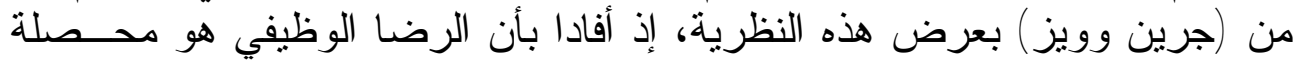

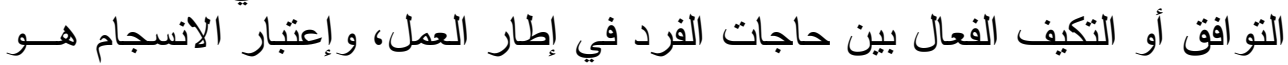

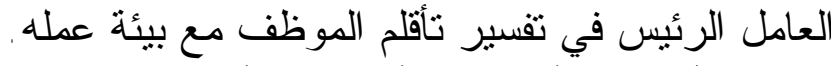

\section{4. نظرية المقارنة (المقارنة المرجعية)}

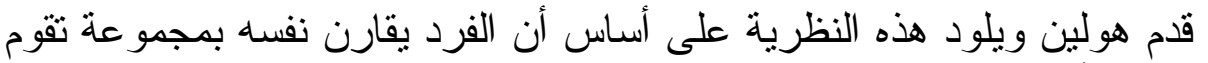

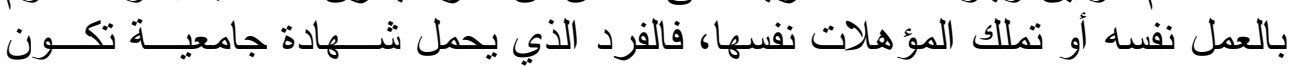

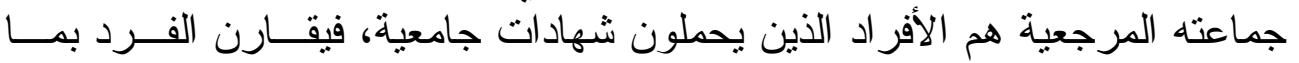

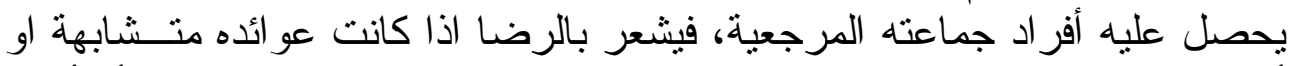

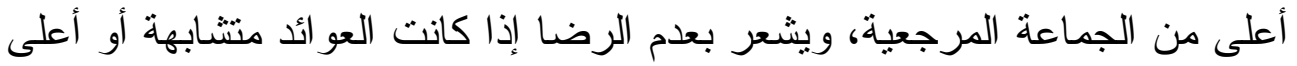
من الجماعة المرجعية.

\section{5. نظرية المقاومة}

يثير الباحثون (كامل و آخرون، 1990، 192) في علم الإدارة إلى أن لاندي

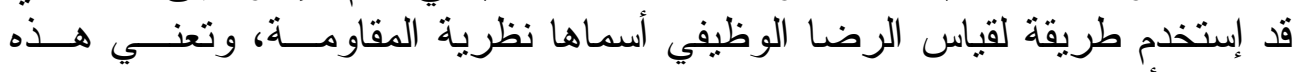

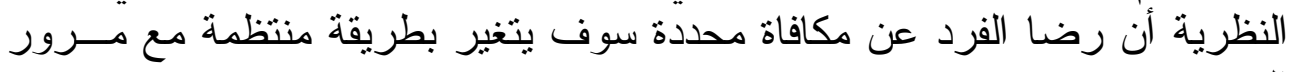

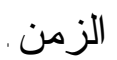

خامساً - طرائق قياس الرضا الوظيفي

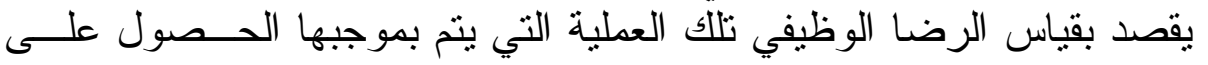

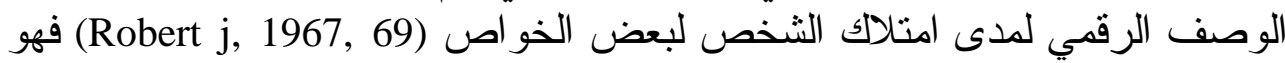

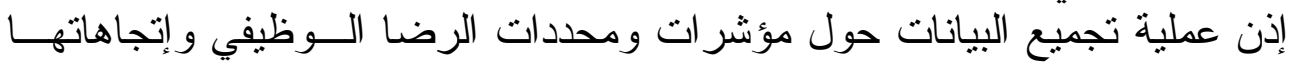




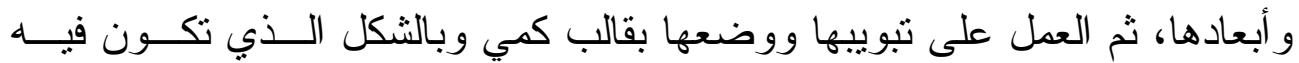

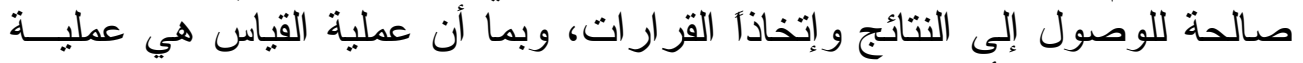

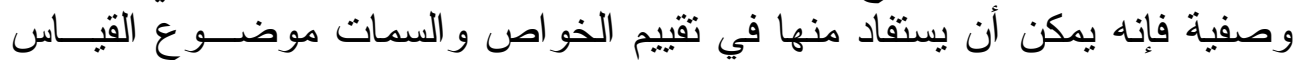

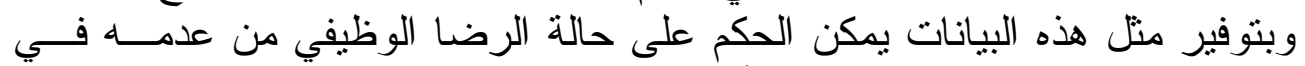

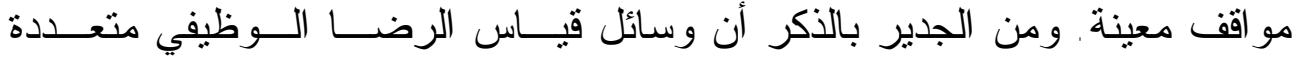

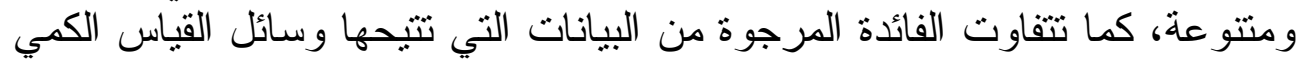
بتفاوت التفصيل الذي تحتويه هذه الوسائل.

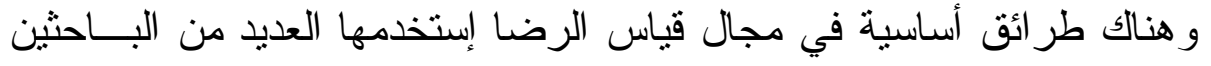

1. طريقة المقابلات الشخصية: (العنزي، 1985، 31) وتعد من أفــضل الطـــرق

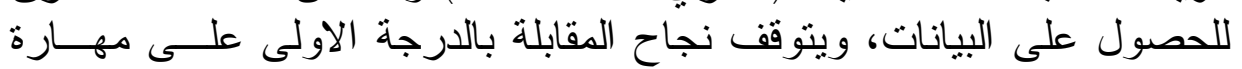
المقابل (بكسر الباء) إذ يمكن بمهارته أن يحصل على البيانات الجيدة.

2. طريقة رواية القصة (طريقة ثنائية العوامل) : اقترح هذه الطريقــة هيرزبــرج

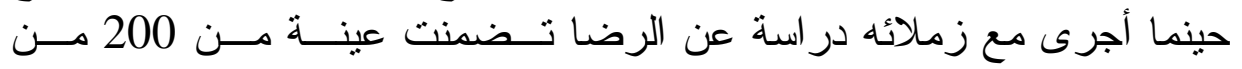

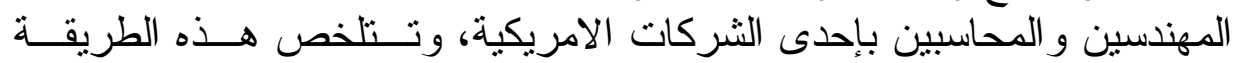

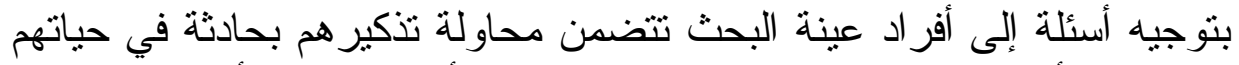

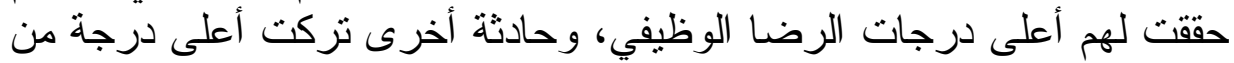

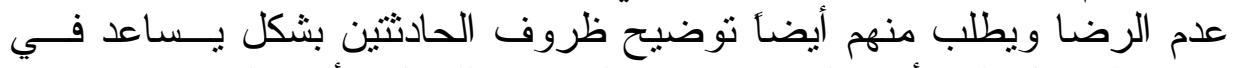

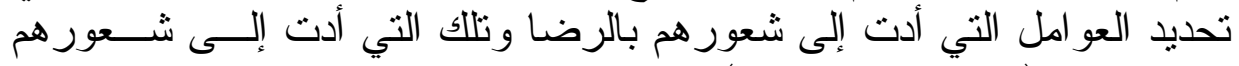
بعدم الرضا (robert j, 1967, 70).

3. طريقة الاستقصاءات : تعتمد هذه الطريقة على قائمة استقصاء تحتوي مجموعة القاء

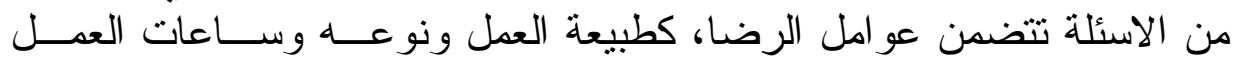

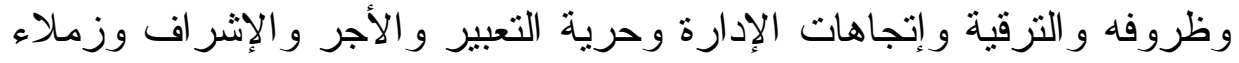

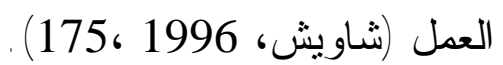

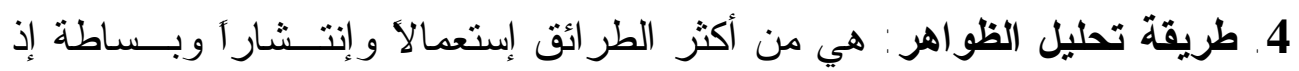

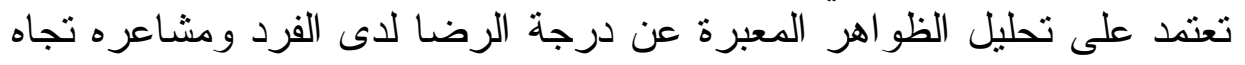
ووظيفته كدور ان العمل ومعدل الغياب وترك الكو الخدمة.

$$
\text { 1الجاتب - الميداني }
$$




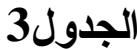

التوزيعات التكرارية والاوساط الحسابية والإحر اف المعياري

لمتغير الحوافز المادية

\begin{tabular}{|c|c|c|c|c|c|c|c|c|c|c|c|c|}
\hline \multirow{3}{*}{ 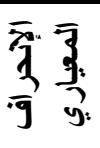 } & \multirow{3}{*}{$\begin{array}{ll}\overline{3} & \overline{3} \\
\overline{3} & \overline{3}\end{array}$} & \multicolumn{10}{|c|}{ قياس الاستجابة } & \multirow{3}{*}{$\begin{array}{l}3 \overline{3} \\
3 \\
3 \\
3\end{array}$} \\
\hline & & \multicolumn{2}{|c|}{ لا اتفق يشدة } & \multicolumn{2}{|c|}{ لا اتفق } & \multicolumn{2}{|c|}{ محايد } & \multicolumn{2}{|c|}{ اتفق } & \multicolumn{2}{|c|}{ اتفق بشدة } & \\
\hline & & $\%$ & $ت$ & $\%$ & ت & $\%$ & $ت$ & $\%$ & ت & $\%$ & ت & \\
\hline 0.88 & 1.61 & 58.9 & 53 & 27.8 & 25 & 6.7 & 6 & 6.7 & 6 & * & $*$ & $\mathrm{X} 1$ \\
\hline 0.99 & 1.8 & 47.8 & 43 & 34.4 & 31 & 11.1 & 10 & 3.3 & 3 & 3.3 & 3 & $\mathrm{X} 2$ \\
\hline 1.03 & 1.62 & 62.2 & 56 & 25.6 & 23 & 4.4 & 4 & 3.3 & 3 & 4.4 & 4 & $\mathbf{X 3}$ \\
\hline 0.93 & 1.65 & 60.0 & 54 & 20.0 & 18 & 15.6 & 14 & 3.3 & 3 & 1.1 & 1 & $\mathrm{X4}$ \\
\hline 0.93 & 1.85 & 49 & 54.4 & 20.0 & 18 & 21.1 & 19 & 4.4 & 4 & * & $*$ & $\mathrm{X5}$ \\
\hline 0.70 & 1.42 & 70.0 & 63 & 17.8 & 16 & 12.2 & 11 & * & * & * & $*$ & X6 \\
\hline 1.02 & 1.86 & 50.0 & 45 & 23.3 & 21 & 16.7 & 15 & 10.0 & 9 & $*$ & $*$ & $\mathrm{X} 7$ \\
\hline 1.09 & 1.82 & 51.1 & 46 & 30.0 & 27 & 8.9 & 8 & 5.6 & 5 & 4.4 & 4 & $\mathbf{X 8}$ \\
\hline 0.83 & 1.73 & 47.8 & 43 & 34.4 & 31 & 14.4 & 13 & 3.3 & 3 & $*$ & $*$ & X9 \\
\hline 1.22 & 2.47 & 25.6 & 23 & 30.0 & 27 & 23.3 & 21 & 13.3 & 12 & 7.8 & 7 & $\mathrm{X10}$ \\
\hline 1.94 & 4.2 & 38.0 & 23.3 & 21.0 & 32.2 & 29 & 2.2 & 2 & $*$ & $*$ & $\mathrm{X} 6$ & X11 \\
\hline 0.83 & 1.61 & 61.1 & 55 & 16.7 & 15 & 22.2 & 20 & $*$ & * & $*$ & $*$ & $\mathrm{X12}$ \\
\hline 1.03 & 1.97 & & 2.1 & & & $\% 1$ & & $\% 4$ & & & & الكوأشي \\
\hline
\end{tabular}

تثنير معطيات الجدول 3 الخاصة بالتوزيعات التكر ارية و الأوساط الحسـسابية

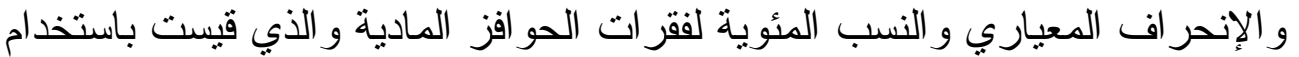

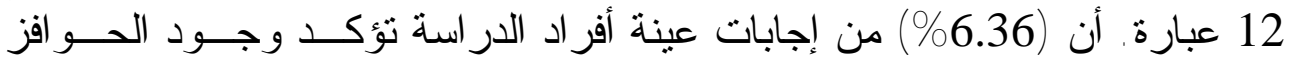

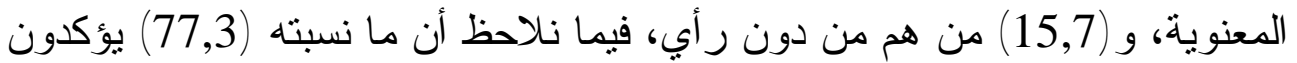

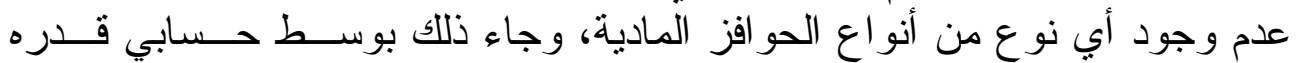

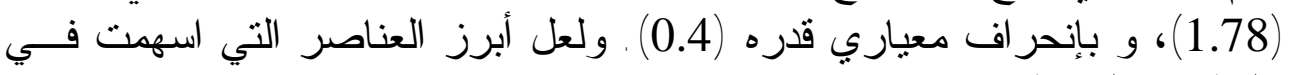

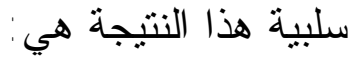

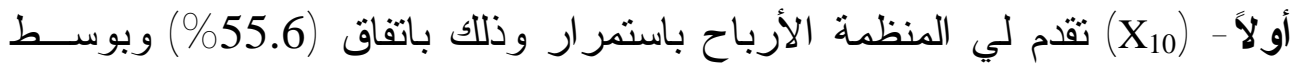

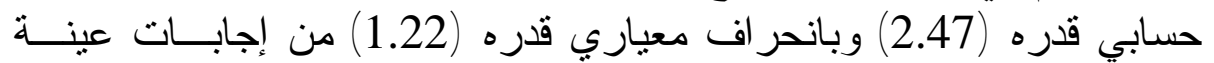
الدر اسة. 


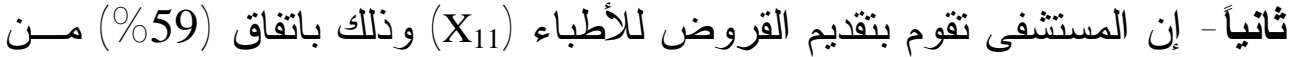

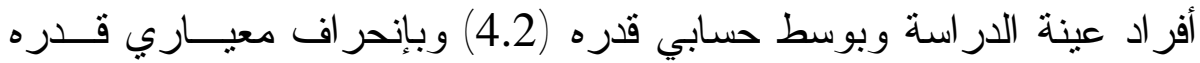

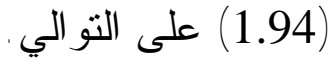

2. وصف متغيرات الحو افز المعنوية وتثخيصها

\section{الجدول 4}

التوزيعات التكرارية و الاوساط الحسابية والإحر اف المعياري لمتغير الحو افز المعنوية الإبية

\begin{tabular}{|c|c|c|c|c|c|c|c|c|c|c|c|c|}
\hline \multirow{3}{*}{$\begin{array}{l}\overline{\bar{y}} \\
\bar{y} \\
\bar{y} \\
\overline{3} \\
\bar{y}\end{array}$} & \multirow{3}{*}{$\begin{array}{l}\overline{3} \\
\overline{3} \\
\overline{7} \\
\frac{3}{3}\end{array}$} & \multicolumn{10}{|c|}{ قياس الاستجابة } & \multirow{3}{*}{ 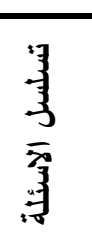 } \\
\hline & & \multicolumn{2}{|c|}{ لا اتفق يثدة } & \multicolumn{2}{|c|}{ لا اتفق } & \multicolumn{2}{|c|}{ محايد } & \multicolumn{2}{|c|}{ اتفق } & \multicolumn{2}{|c|}{ بثدة } & \\
\hline & & $\%$ & $ت$ & $\%$ & $ت$ & $\%$ & ت & $\%$ & $ت$ & $\%$ & ت & \\
\hline 1.14 & 2.73 & 17.8 & 16 & 22.2 & 20 & 35.6 & 32 & 17.8 & 16 & 6.7 & 6 & $\mathrm{X13}$ \\
\hline 1.02 & 2.28 & 21.1 & 19 & 38.9 & 35 & 30.3 & 30 & 3.3 & 3 & 3.3 & 3 & $\mathrm{X14}$ \\
\hline 0.970 & 2.08 & 28.9 & 26 & 33.3 & 30 & 27.8 & 25 & 10.0 & 9 & $*$ & * & X15 \\
\hline 0.921 & 2.25 & 24.4 & 22 & 25.6 & 23 & 43.3 & 39 & 6.7 & 6 & $*$ & * & $\begin{array}{l}\mathrm{X} \\
\end{array}$ \\
\hline 0.715 & 1.6 & 50.0 & 45 & 43.3 & 39 & 3.3 & 3 & 3.3 & 3 & $*$ & * & $\begin{array}{l}\mathbf{X 1 7} \\
\end{array}$ \\
\hline 0.936 & 2.23 & 36.7 & 33 & 10.0 & 9 & 46.7 & 42 & 6.7 & 6 & $*$ & 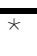 & X18 \\
\hline 0.936 & 2.27 & 18.9 & 17 & 45.6 & 41 & 27.8 & 25 & 4.4 & 4 & 3.3 & 3 & X19 \\
\hline 0.878 & 2.05 & 28.9 & 26 & 43.3 & 39 & 21.1 & 19 & 6.7 & 6 & $*$ & * & $\mathbf{X 2 0}$ \\
\hline 1.08 & 2.16 & 18.9 & 17 & 32.2 & 29 & 35.6 & 32 & 6.7 & 6 & $\begin{array}{l}6.7 \\
\end{array}$ & 0 & $\mathrm{X} 21$ \\
\hline 0.796 & 1.71 & 50.0 & 45 & 28.9 & 26 & 21.1 & 19 & $*$ & $*$ & ${ }^{*}$ & * & $\mathrm{X} 22$ \\
\hline 0,32 & 3.8 & 29.56 & & 32.33 & & 29.26 & & 6,55 & & 2 & & الكلي \\
\hline
\end{tabular}

تثتير معطيات الجدول 4 الخاصة بالتوزيعات التكر ارية و الأوساط الحسـسابية

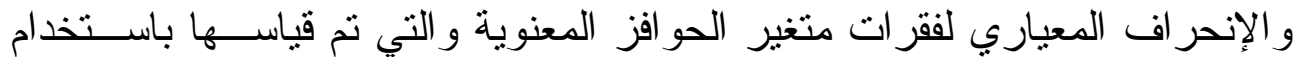

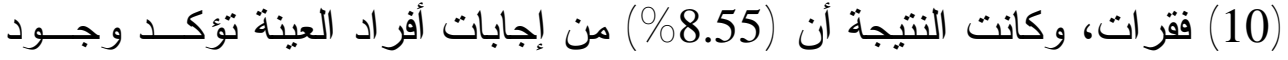

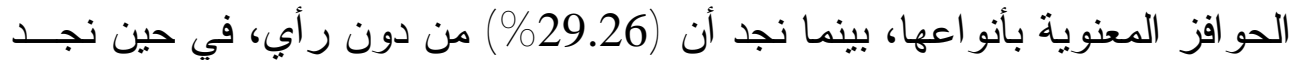

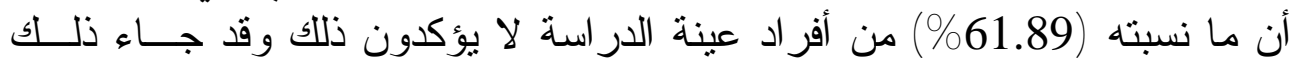


بوسط حسابي كلي قدره (3.8) وبإنحر اف معياري قدره (0.32) و هنالك عنصر ان أيضاً أسهما في سلتبية هذه النتائج:

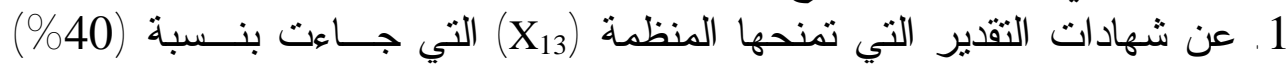

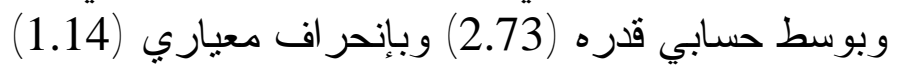

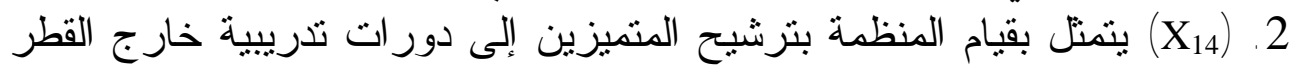

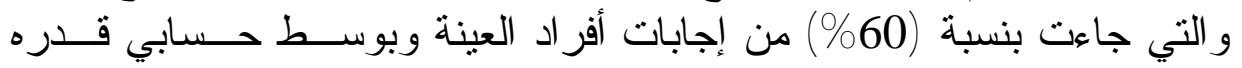
(2.28) وبإنحر اف معياري قدره (1.02) من الجابات أنرات

3: وصف متغيرات الرضا الوظيفي وتثخيصها

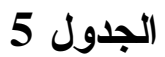

التوزيعات التكرارية والاوساط الحسابية و الإنحر اف المعياري لمتغير

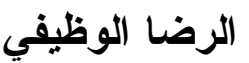

\begin{tabular}{|c|c|c|c|c|c|c|c|c|c|c|c|c|}
\hline \multirow{3}{*}{ 高 } & \multirow{3}{*}{$\begin{array}{l}\overline{3} \\
\overline{3} \\
3\end{array}$} & \multicolumn{10}{|c|}{ قياس الاستجابة } & \multirow{3}{*}{ 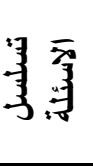 } \\
\hline & & \multicolumn{2}{|c|}{ لا اتفق يشدة } & \multicolumn{2}{|c|}{ لا اتفق } & \multicolumn{2}{|c|}{ محايد } & \multicolumn{2}{|c|}{ اتفق } & \multicolumn{2}{|c|}{ اتفق بشدة } & \\
\hline & & $\%$ & 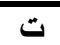 & $\%$ & $ت$ & $\%$ & ت & $\%$ & ت & $\%$ & ت & \\
\hline 1.36 & 2.92 & 11.1 & 10 & 35.6 & 32 & 25.6 & 23 & 15.6 & 14 & 12.2 & 11 & $\mathrm{X23}$ \\
\hline 1.01 & 2.11 & 42.2 & 38 & 23.3 & 21 & 23.3 & 21 & 3.3 & 3 & 7.8 & 7 & $\mathrm{X24}$ \\
\hline 1.01 & 2.74 & 18.9 & 17 & $\overline{44.4}$ & $\overline{40}$ & 15.6 & 14 & 14.4 & 13 & 6.7 & 6 & $\mathbf{X 2 5}$ \\
\hline 1.05 & 2.6 & 30.0 & 27 & 33.3 & 30 & 16.7 & 15 & 3.3 & 3 & 16.7 & 15 & $\mathrm{X} 26$ \\
\hline 1.04 & 2.82 & 27.8 & 25 & 37.8 & 34 & 7.8 & 7 & 7.8 & 7 & 18.9 & 17 & X27 \\
\hline 1.04 & 2.54 & 38.9 & 35 & 33.3 & 30 & 15.6 & 14 & 6.7 & 6 & 5.6 & 5 & $\mathrm{X} 28$ \\
\hline 0.92 & 3.54 & 14.4 & 13 & 35.6 & 32 & 3.3 & 3 & 6.7 & 6 & 40.0 & 36 & $\mathrm{X29}$ \\
\hline 1.10 & 2.76 & 25.6 & 23 & 41.1 & 37 & 3.3 & 3 & 17.8 & 16 & 12.2 & 11 & X30 \\
\hline 1.01 & 2.95 & 30.0 & 27 & 32.2 & 29 & 4.4 & 4 & 6.7 & 6 & 26.7 & 24 & X31 \\
\hline 0.92 & 3.03 & 22.2 & 20 & 45.6 & 41 & 3.3 & 3 & 6.7 & 6 & 22.2 & 20 & $\mathrm{X32}$ \\
\hline 0.97 & 3.01 & 16.7 & 15 & 54.4 & 49 & 3.3 & 3 & 13.3 & 12 & 12.2 & 11 & $\mathbf{X 3 3}$ \\
\hline 1.00 & 2.94 & 28.9 & 26 & 35.6 & 32 & 3.3 & 3 & 8.9 & 8 & 23.3 & 21 & X34 \\
\hline 1.09 & 3.14 & 16.7 & 15 & 38.9 & 35 & 11.1 & 10 & 7.8 & 7 & 25.6 & 23 & $\mathrm{X35}$ \\
\hline 1.03 & 3.15 & 21.1 & 19 & 41.1 & 37 & 14.4 & 13 & 3.3 & 3 & 20.0 & 18 & $\mathrm{X36}$ \\
\hline 1.07 & 3.2 & 21.1 & 19 & 32.3 & 29 & 7.8 & 7 & 7.8 & 7 & 31.1 & 28 & X37 \\
\hline 1.09 & 2.96 & 31.1 & 28 & 24.4 & 22 & 7.8 & 7 & 6.7 & 6 & 30.0 & 27 & X38 \\
\hline 1.17 & 2.55 & 31.1 & 28 & 26.7 & 24 & 20.0 & 18 & 6.7 & 6 & 15.6 & 14 & X39 \\
\hline 1.04 & 3.38 & 10.0 & 9 & 43.3 & 39 & 7.8 & 7 & 11.1 & 10 & 27.8 & 25 & $\mathrm{X40}$ \\
\hline 1.03 & 2.12 & 37.8 & 34 & 23.3 & 21 & 28.9 & 26 & 3.3 & 3 & 6.7 & 6 & $\overline{X 41}$ \\
\hline 0,99 & 2,90 & 24, & & & & 10 & & & & 1 & & الكوئشي \\
\hline
\end{tabular}


تشير معطيات الجدول 5 الخاصة بالتوزيعات التكر ارية و الأوساط الحسـابية

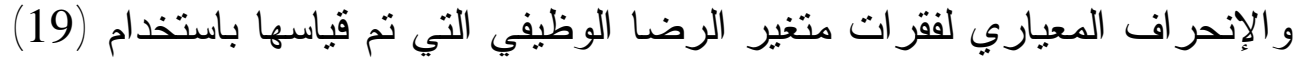

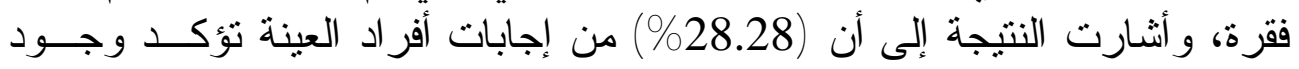

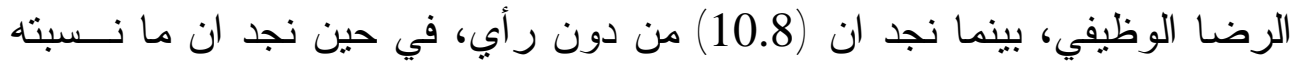

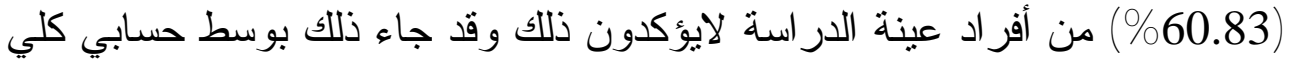

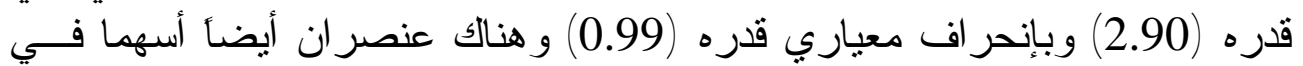

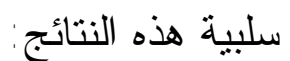

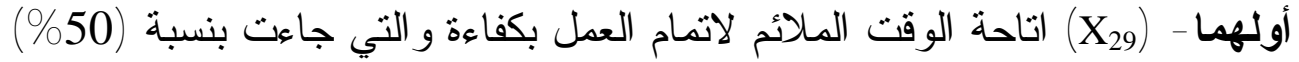

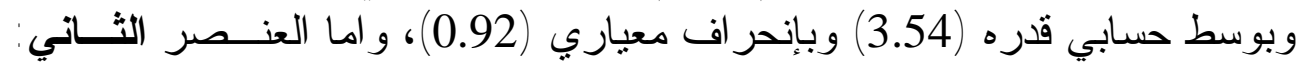

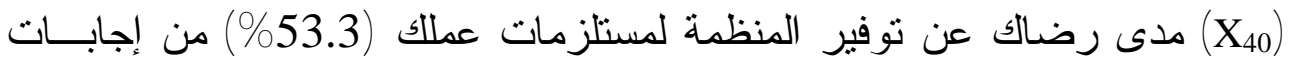
أفر اد العينة وبوسط حسابي قدره (3.38) و بإنحر اف معياري قدره (1.04).

ثانياً - تحليل متغير ات البحث 1. تحليل علاقات الإرتباط بين متغيرات البحث

\begin{tabular}{|c|c|}
\hline \multicolumn{2}{|c|}{ نتائج علاقة الإرتباط والاثر بين متغيرات الدراسة } \\
\hline الحو افز & تفسيري \\
\hline$* 0.656$ & الرضا الوظيفي \\
\hline
\end{tabular}

يعرض الجدول 6 نتائج تحليل علاقة الإرتباط بين المتغير المستقل و المتمتل

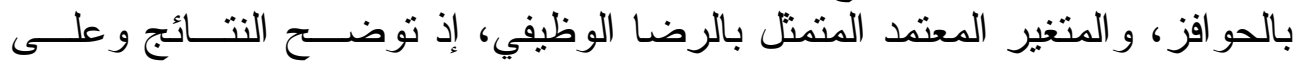

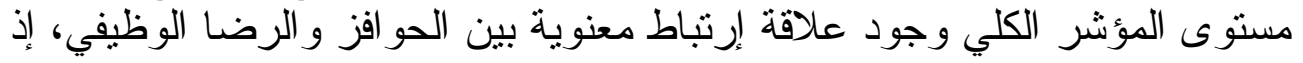

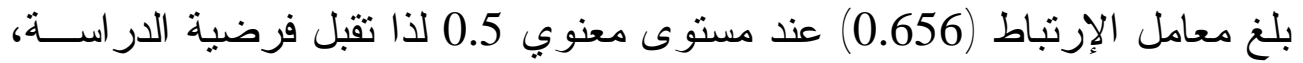

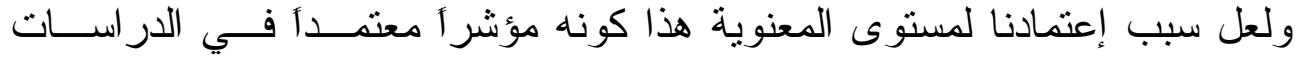
الانسانية على المستوى العالمي.

2. تحليل علاقة الاثر بين متغيرات البحث

تحليل التباين لأموذج الإحدار المتعدد 7 ANOVA




\begin{tabular}{|l|c|c|c|c|c|c|}
\hline \multicolumn{1}{|c|}{ Model } & $\begin{array}{c}\text { Sum of } \\
\text { squares }\end{array}$ & Df & $\begin{array}{c}\text { Mean } \\
\text { square }\end{array}$ & R2 & F & Sig \\
\hline Regression & 5.444 & 1 & 5.444 & 0,7 & 13.586 & 0.002 \\
Residual & 45.295 & 88 & 0.515 & & & \\
Total & 50.739 & 89 & & & \multicolumn{5}{|c|}{$\mathrm{R} 2=0.70$} \\
\hline
\end{tabular}

تشير نتائج الإنحدار المتعدد في الجدول 7 إلى وجود علاقة تأثير معنويـــة

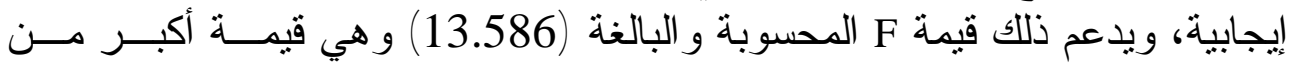

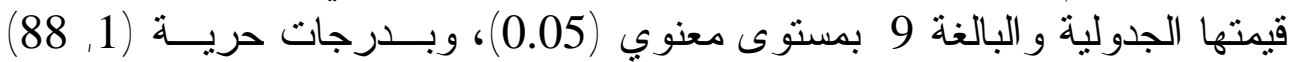

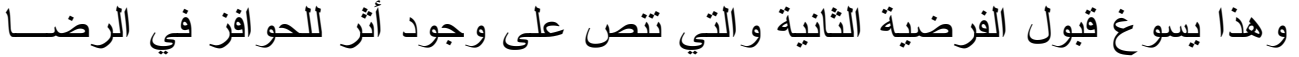

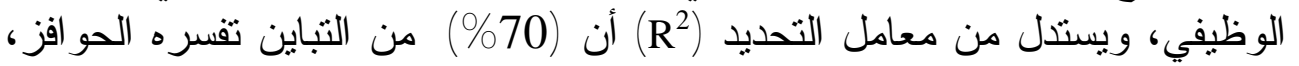
أما البقية و التي مقدارها (30\%) هي متغير ات عشو ائية لايمكن السيطرة علئها

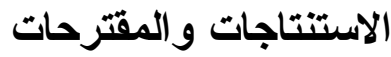
أولاً - الاستنتاجات والمات

1. يعد نظام الحوافز الحجر الأساس في صنع نطور المنات المنظمات عمومأ والــصحية خصوصأ لما لها من أثر بالغ في الأقر اد.

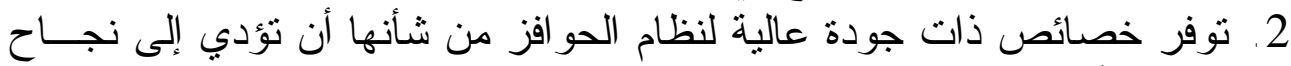

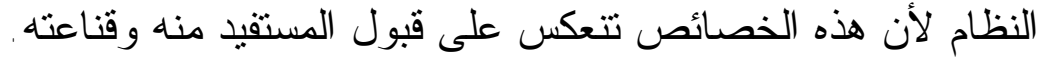

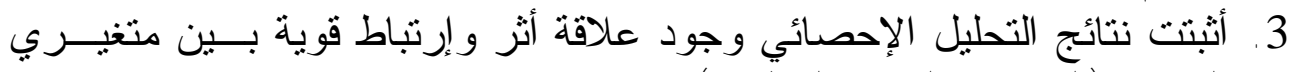

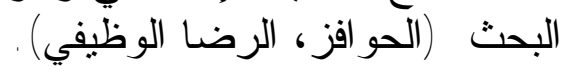

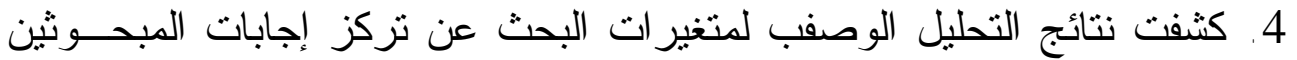

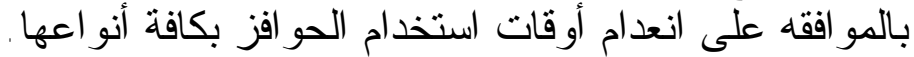

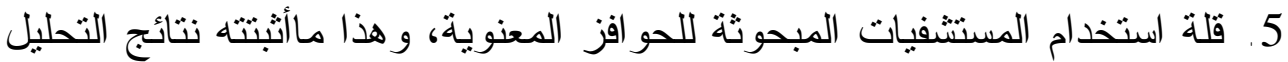

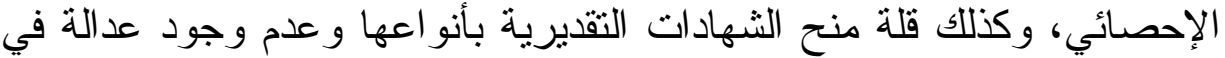

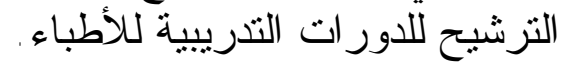

ثُانياً - المقترحات 1. ضرورة أن تتبنى المنظمات عينة الدراسة استخدام الحوافز أبعادها كافة (مادية

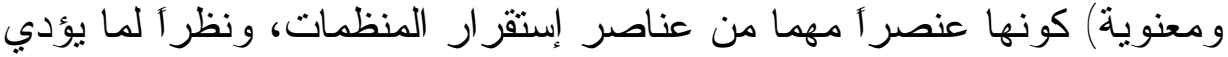

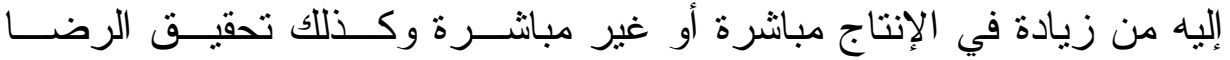

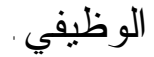

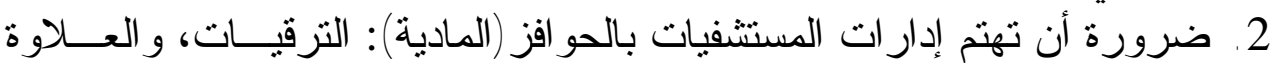

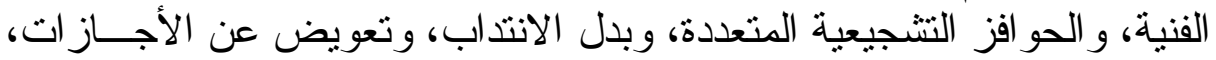

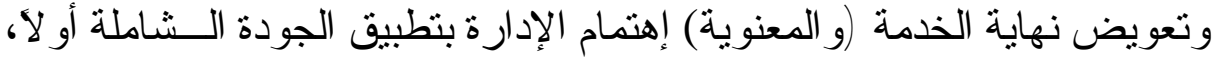

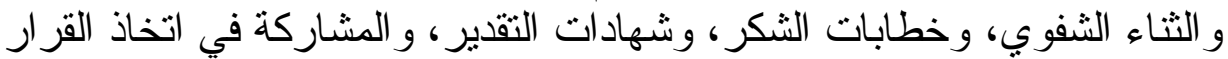

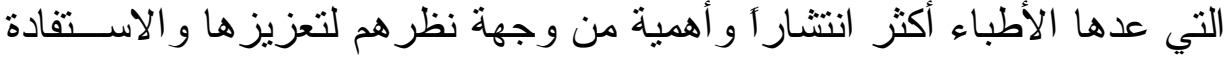


الدكتور عباس ويونس [242]

منها في عملية التخطيط لنظام حو افز فعال من أجل زيادة كفاءة الأداء للأطبـــاء

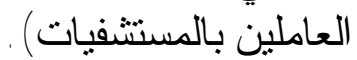

\section{المراجع

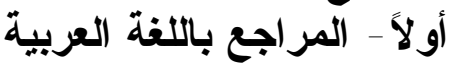

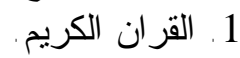

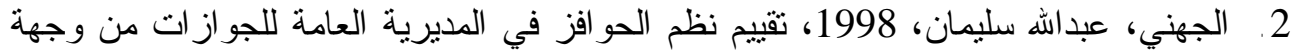

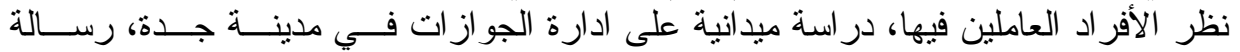
ماجستير غير منشورة، الرياض فئ.

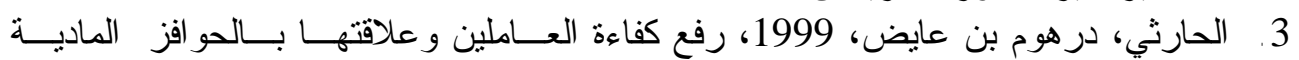

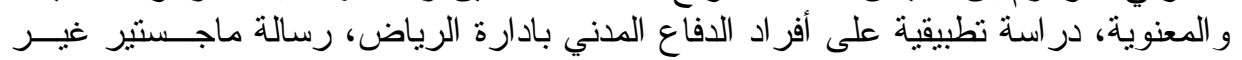

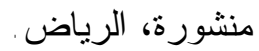

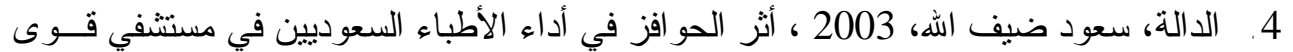

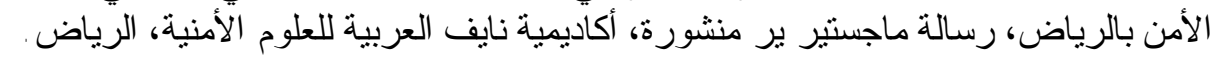

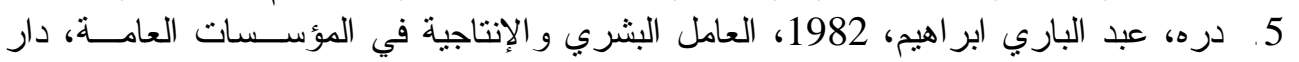

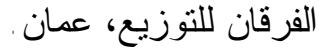

6. السالم، سالم محمد، 1997، الرضان الريا الوظيفي للعاملين في المكتبات الجامعية بالمملكة العربية

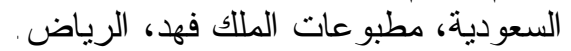
7. شاويش، مصطفى نجيب، 1996، ادارة المو ارد البشرية و ادارة الأفر اد، دار الثروق للنشر لللتوزيع، عمان . 8. العبادي، عطاف، 2005، دراسة العوامل المرتبطبة بالرضا الوظيفي لدى العاملين الإداريين

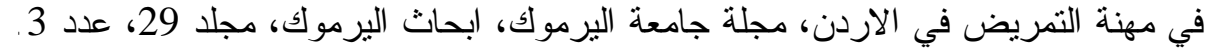

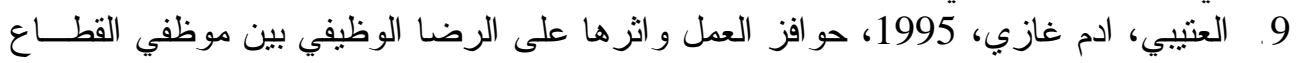

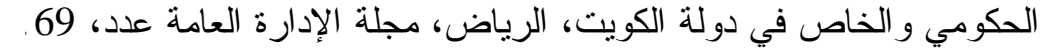

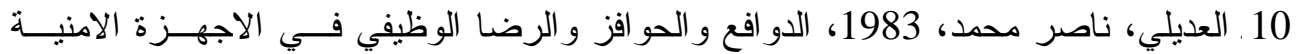

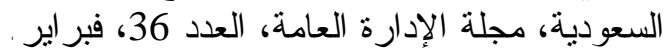

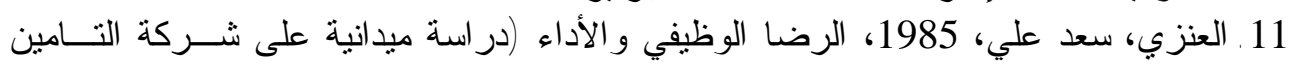

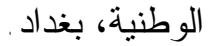

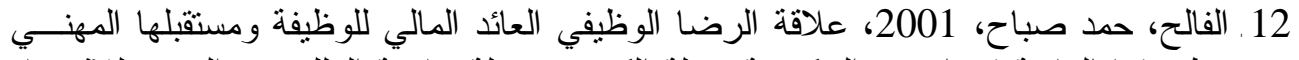

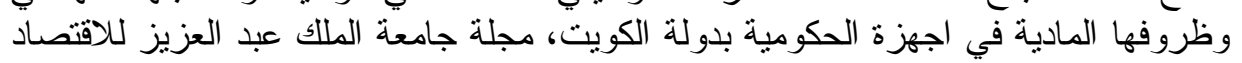

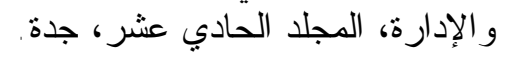
13 فههي، منصور، 1988 ، إدارة الأفر اد، المطابع الاميرية، القاهرة.

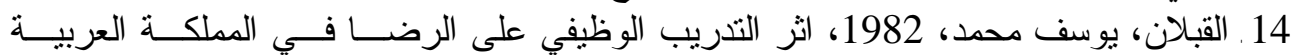

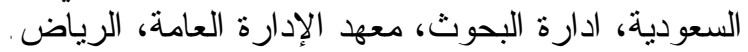
15. القريوتي، محمد قاسم، 2001، مبادئ، الإدة الإدارة (النظريات و العمليات و الوظائف)، د دار صفاء للطباعة و النشر ، عمان.

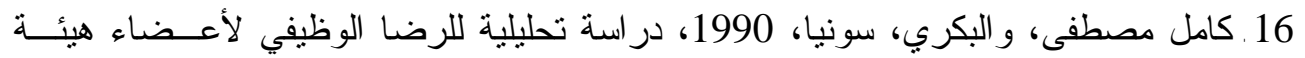

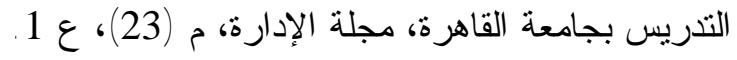




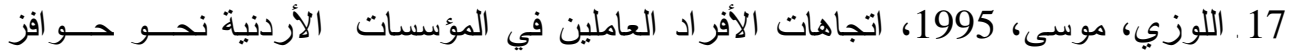

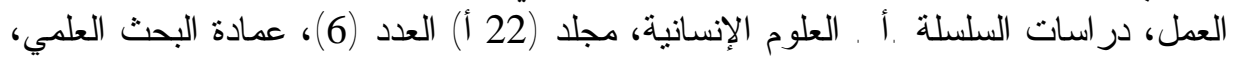

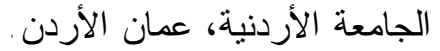

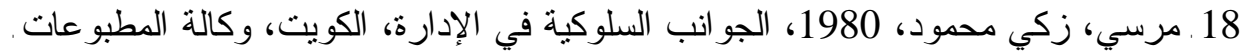

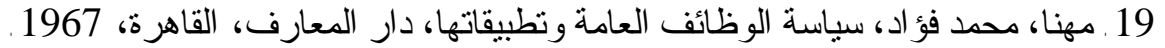

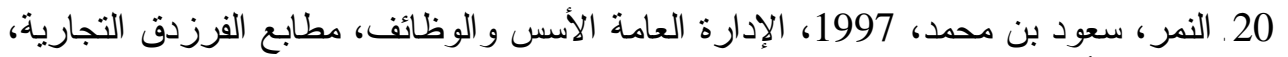

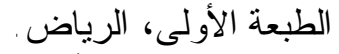

ثانياً - المر اجع باللغة الاجنية الاجنبية

1.F.Landy And D.Trumbo.Psychoiogyof Work Behavior, Homewood: Thedorsey Press. 1980.

2. Mintzberg, H., 1979, The Structuring Of Organizations, Englewood Cliffs, NJ: Prentice Hall.

3. Robert J, 1967, “The Strategic Management Process", $3^{\text {rd }}$ Ed, United State Of America Press.

4. Vroom, Katch .D ,1978, "What Is A Management Information System” Infosvstem., V Work And Motivation, (New York: John Wiley And Eons. 1964). 